\title{
Secreted and Transmembrane Wnt Inhibitors and Activators
}

\author{
Cristina-Maria Cruciat ${ }^{1}$ and Christof Niehrs ${ }^{1,2}$ \\ ${ }^{1}$ Division of Molecular Embryology, DKFZ-ZMBH Alliance, DKFZ, Im Neuenheimer Feld 280, D-69120 \\ Heidelberg, Germany \\ ${ }^{2}$ Institute of Molecular Biology, D-55128 Mainz, Germany \\ Correspondence: niehrs@dkfz-heidelberg.de
}

Signaling by the Wnt family of secreted glycoproteins plays important roles in embryonic development and adult homeostasis. Wnt signaling is modulated by a number of evolutionarily conserved inhibitors and activators. Wnt inhibitors belong to small protein families, including sFRP, Dkk, WIF, Wise/SOST, Cerberus, IGFBP, Shisa, Waif1, APCDD1, and Tiki1. Their common feature is to antagonize Wnt signaling by preventing ligand-receptor interactions or Wnt receptor maturation. Conversely, the Wnt activators, R-spondin and Norrin, promote $\mathrm{Wnt}$ signaling by binding to $\mathrm{Wnt}$ receptors or releasing a Wnt-inhibitory step. With few exceptions, these antagonists and agonists are not pure Wnt modulators, but also affect additional signaling pathways, such as TGF- $\beta$ and FGF signaling. Here we discuss their interactions with Wnt ligands and Wnt receptors, their role in developmental processes, as well as their implication in disease.

W nt signaling is regulated at different levels by a wide range of effectors. These effectors function as agonists or antagonists and act either intracellularly to modulate components of the signal transduction machinery or extracellularly to modulate ligand-receptor interactions. Antagonists and agonists are of great importance, as they control the fine-tuning of Wnt signaling and inhibit or activate Wnt-regulated developmental processes, such as anteriorposterior (AP) axial patterning, somitogenesis, angiogenesis, vasculogenesis, and limb, bone, tooth, and eye formation, and they are implicated in pathological events, including cancer and bone disease. Six families of secreted and four families of transmembrane Wnt antagonists are known to date: the Dickkopf proteins (Dkks), secreted Frizzled-related proteins (sFRPs), Wntinhibitory factor 1 (WIF-1), Wise/SOST, Cerberus, insulin-like growth-factor binding protein 4 (IGFBP-4), Shisa, Wnt-activated inhibitory factor 1 (Waif1/5T4), adenomatosis polyposis coli down-regulated 1 (APCDD1), and Tikil, the latter four being transmembrane. Among them, the Dkk protein family is best characterized. Two families of growth factors are known to activate Wnt signaling besides Wnts, Norrin, and R-spondins (Rspo). These protein families are not related to each other, and some of them act specifically on canonical Wnt signaling, whereas others affect both canonical and noncanonical Wnt pathways. This

Editors: Roel Nusse, Xi He, and Renee van Amerongen

Additional Perspectives on Wnt Signaling available at www.cshperspectives.org

Copyright (C) 2013 Cold Spring Harbor Laboratory Press; all rights reserved; doi: 10.1101/cshperspect.a015081

Cite this article as Cold Spring Harb Perspect Biol 2013;5:a015081 
review describes the individual families and their members, with emphasis on their structure, mode of action, and role in development and disease. Related reviews examining Dkks (Niehrs 2006), sFRPs (Jones and Jomary 2002; Kawano and Kypta 2003; Bovolenta et al. 2008), Cerberus (Belo et al. 2009), and Rspo family members (Yoon and Lee 2012) are available.

\section{SECRETED WNT INHIBITORS}

\section{Dkk Protein Family}

\section{Physical Properties and Structure}

Dkks represent a small family of evolutionarily conserved secreted glycoproteins. The founding member of the family, Dkk1, was identified as embryonic head inducer and Wnt antagonist in Xenopus (Glinka et al. 1998). Since then, Dkks were identified in other vertebrates, including humans, as well as in invertebrates such as Dictyostelium, cnidarians, urochordates, and ascidians, but not in Drosophila and Caenorhabditis elegans. For a more comprehensive overview on the topic, the reader is referred to Niehrs (2006). In vertebrates, the Dkk family comprises four members, Dkk1-4. They consist of 255-350 amino acids and share two conserved cysteinerich domains (CRDs) (Fig. 1). Whereas the amino-terminal CRD, DKK_N, is unique to the Dkks, the carboxy-terminal CRD shows homology with the colipase fold, a domain found in a wide range of functionally unrelated proteins, including, for example, colipases, toxins, protease inhibitors, and prokineticins (Niehrs 2006). In addition to the two CRDs, an sgy domain is found only in Dkk3 (see below).

Dkk3 appears to be a divergent member of the Dkk family. In contrast to $D k k 1,-2$, and -4 , which are more related to each other than they are to $D k k 3$ (Glinka et al. 1998), Dkk3 shares sequence homology with $\operatorname{soggy}(\operatorname{sgy})$, a distant Dkk family member, also called Dickkopf-like protein 1 (Krupnik et al. 1999). In addition, Cnidaria, Hydra, and Nematostella each have only two $D k k$ genes, one related to vertebrate Dkk1, -2, and -4 (Guder et al. 2006) and one related to vertebrate $D k k 3$ (Fedders et al. 2004). Furthermore, human $D k k 1,-2$, and - 4 are locat- ed on the same chromosome 4/5/8/10 paralogy group, genes of which duplicated early in vertebrate evolution (Pollard and Holland 2000; Luke et al. 2003), but Dkk3 is not part of this group.

Little is known about Soggy outside of a potential role in spermatogenesis and its homology with Dkk3 (Kaneko and DePamphilis 2000; Kohn et al. 2005).

\section{Mechanism of Action}

Of the various signaling pathways activated by Wnts, Dkks specifically inhibit the Wnt/ $\beta$-catenin signaling cascade. Dkk1 and Dkk2 bind to low-density lipoprotein receptor-related protein (LRP) 5/6 with high affinity and an apparent $K_{\mathrm{d}}$ in the range of 0.3 to $0.7 \mathrm{~nm}$ (Bafico et al. 2001; Mao et al. 2001; Semenov et al. 2001). As for Dkk1 and Dkk2, a functional interaction with LRP6 has been shown for Dkk4. In contrast, Dkk3 does not bind LRP6 and does not affect Wnt signaling (Mao et al. 2001; Mao and Niehrs 2003), but rather regulates transforming growth factor- $\beta$ (TGF- $\beta$ ) signaling (Pinho and Niehrs 2007). Within LRP6, the last two YWTD-epidermal growth factor (EGF) repeat domains mediate binding to Dkk1 (Mao et al. 2001). Within Dkk1, the colipase fold, but not the DKK_N domain, is sufficient for LRP6 binding and Wnt inhibition (Brott and Sokol 2002; Li et al. 2002; Mao and Niehrs 2003), and mutation of the conserved Cys-220 of the colipase fold abolishes the interaction (Semenov et al. 2001).

Genetic evidence for a Dkk1 -LRP6 interaction is provided by the rescue of severe developmental defects of LRP6- and Dkk1-null mice observed in LRP6/Dkk1 double-knockout mice (MacDonald et al. 2004).

In addition to LRP5/6, Dkks bind with high affinity to another class of receptors, Kremen 1 and $2(\mathrm{Krm} 1 / 2)$, evolutionarily conserved single-pass transmembrane proteins. They contain a Kringle, WSC, and CUB domain, which are all required for Dkk1 interaction, and an intracellular domain without obvious sequence motifs (Mao et al. 2002). Kremens bind both Dkk1 and Dkk2 but not Dkk3 with an apparent $K_{\mathrm{d}}$ in the nanomolar range (Mao et al. 2002). Similar to 
Wnt Inhibitors and Activators
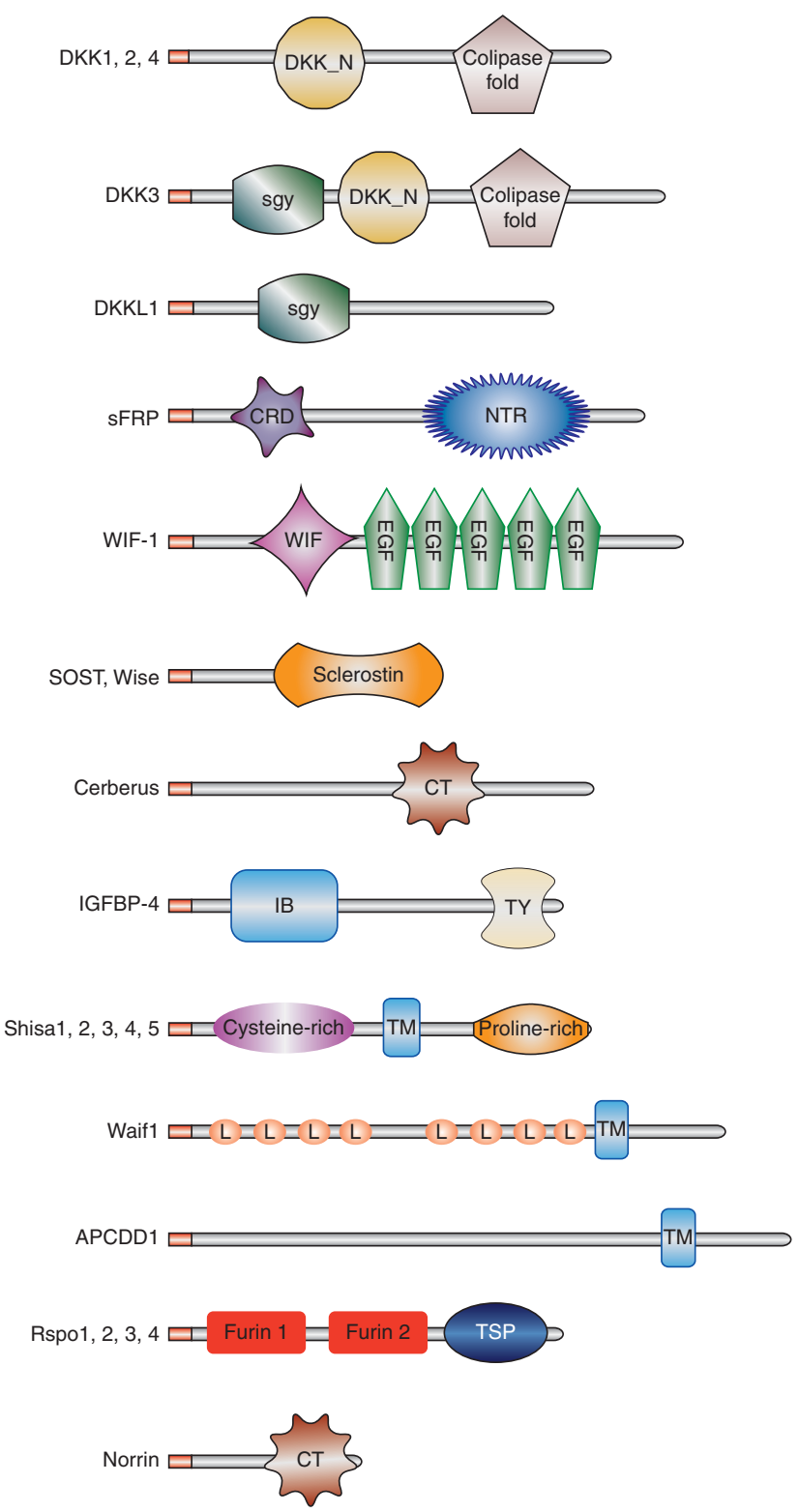

Figure 1. Domain structure of Wnt antagonists and agonists. Signal peptides are shown in red. NTR, Netrinrelated motif; WIF, Wnt-inhibitory factor 1 domain; EGF, epidermal growth factor-like domain; CT, cystine knot-like domain; IB, insulin growth factor binding protein domain; TY, thyroglobulin type-1 domain; TM, transmembrane domain; L, leucine-rich repeats; TSP, thrombospondin type-1 domain.

the Dkk1-LRP6 interaction, it is the colipase fold of Dkk1, which is necessary and sufficient for Kremen binding (Mao and Niehrs 2003). $\mathrm{Krm} 1 / 2$ greatly potentiate the ability of Dkk1 to inhibit Wnt signaling, and membrane attachment of the Krm2 extracellular domain is criti- cal for its function. Evidence for a functional interaction of these proteins in vivo is provided by loss-of-function experiments. Morpholinomediated knockdown of Krm1/2 in Xenopus embryos induces head defects, which can be rescued by $D k k 1$ mRNA overexpression. In 
addition, there is strong enhancement of head defects when both $D k k 1$ and $K r m 1 / 2$ are inhibited (Davidson et al. 2002). Furthermore, in mice, these proteins genetically interact during limb development, as triple-mutant $\mathrm{Krml}^{-/-} /$ $\mathrm{Krm} 2^{-/-} / D k k 1^{+/-}$mice show enhanced formation of ectopic digits (Ellwanger et al. 2008).

The dominant mode by which Dkk1 acts is to prevent the Wnt-LRP6 interaction and disrupt the Wnt-induced Fz8-LRP6 complex formation (Fig. 2A) (Semenov et al. 2001). In addition, when Kremen is present, Dkk1 can form a ternary complex with Krm2 and LRP6 and induce rapid endocytosis and removal of LRP6 from the plasma membrane (Fig. 2B) (Mao et al. 2002). Recent biochemical studies (Semenov et al. 2008; Wang et al. 2008) and the characterization of $\mathrm{Krm} 1^{-/-} / \mathrm{Krm}^{-/-}$double-mutant mice (Ellwanger et al. 2008) indicate that Kremens are not universally required for Dkk1 function, but rather this interaction is physiologically relevant only in certain tissues, and that the ability of Dkk1 to prevent WntLRP6 interaction may be sufficient for effective Wnt antagonism in many cells.

\section{Dual Role of Dkk2}

Unlike Dkk1, which is a pure inhibitor of Wnt/ $\beta$-catenin signaling, Dkk2 is able to act either as inhibitor or activator of the pathway, depending on the cellular context. When overexpressed in Xenopus, Dkk2 synergizes with coexpressed Fz8 (Wu et al. 2000) or LRP6 (Brott and Sokol 2002) to induce $\mathrm{Wnt} / \beta$-catenin signaling. In contrast, in HEK293T or NIH3T3 cells, Dkk2 inhibits Wnt/ $\beta$-catenin signaling when cotransfected with Wnt and Fz, and activates the pathway when cotransfected with LRP5/6 (Wu et al. 2000; Li et al. 2002; Mao and Niehrs 2003). The colipase fold of Dkk2 is sufficient for this synergy ( $\mathrm{Li}$ et al. 2002). In the presence of Krm2, though, Dkk2 acts as Wnt inhibitor (Mao and Niehrs 2003), indicating that receptor context may determine its action.

Structure-function analysis revealed that the isolated colipase fold of Dkk1 is sufficient to synergize with LRP6 in activating Wnt signaling, whereas its DKK_N domain is important to impart the inhibitory effect. The DKK_N domain of Dkk 2 is neutral in this regard (Brott and Sokol 2002). Thus, whereas the colipase fold of Dkk1/2 mediates binding of Dkks to LRPs, the DKK_N domain modulates the outcome of this interaction (Brott and Sokol 2002).

\section{Role of Dkks in Embryonic Development and Disease}

Given the paramount role that Wnts play during embryonic development, it is not surprising that one main function of Dkks is to control cell fate in vertebrates as they show highly regionalized expression (Grotewold et al. 1999; Monaghan et al. 1999; Hashimoto et al. 2000; Shinya et al. 2000; Chapman et al. 2004; Diep et al. 2004; Idkowiak et al. 2004; Fjeld et al. 2005; Nie 2005; Nie et al. 2005). Dkk1, -2, and -3 mouse mutants are available and a summary of their phenotypes is presented in Table 1.

Dkk1 and AP Axial Patterning. Wnt/ $\beta$-catenin signaling plays an important role in AP patterning of the primary embryonic axis. Together with bone morphogenetic protein (BMP) and Nodal signaling, Wnt/ $\beta$-catenin signaling inhibits anterior development in general, and in particular the anterior central nervous system. This inhibition is prevented by the Spemann organizer in Xenopus, the zebrafish shield, and the mouse anterior mesendoderm, which secretes a cocktail of growth factor antagonists (De Robertis and Kuroda 2004; Niehrs 2004, 2010).

$D k k 1$ was initially identified as a gene conferring Spemann's head organizer activity in Xenopus embryos. $D k k 1$ is specifically expressed in the anterior mesendoderm and induces entire ectopic heads when coexpressed with BMP inhibitors, whereas injection of anti-Dkk1 antibodies yields microcephalic or even headless Xenopus embryos (Glinka et al. 1998). In zebrafish, Dkk1 is also expressed in organizer derivatives of gastrulating embryos (Hashimoto et al. 2000; Shinya et al. 2000) and promotes, when overexpressed, anterior neural development (Hashimoto et al. 2000). These data support the model that Wnt $/ \beta$-catenin signaling inhibits anterior embryonic development, which is prevented by Dkk1. 
Wnt Inhibitors and Activators

A

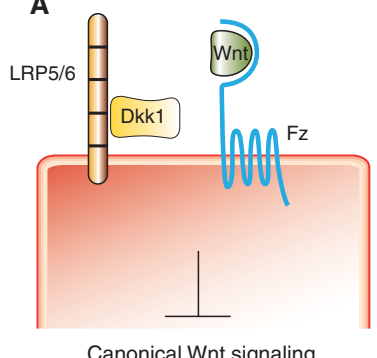

Canonical Wnt signaling

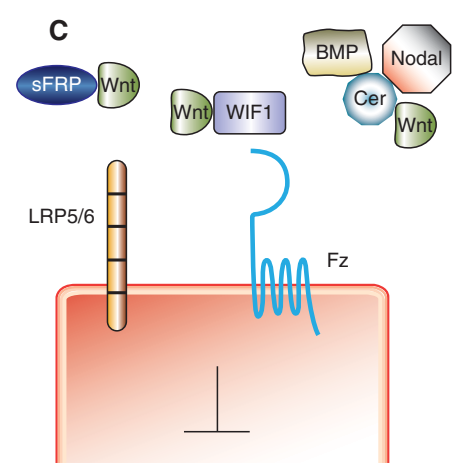

Canonical and noncanonical Wnt signaling

$$
\text { E }
$$

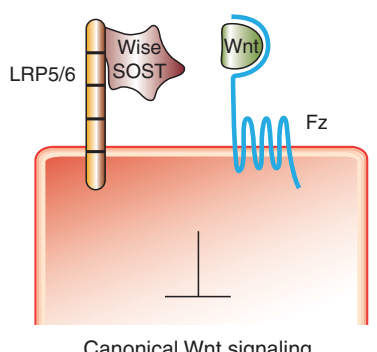

B

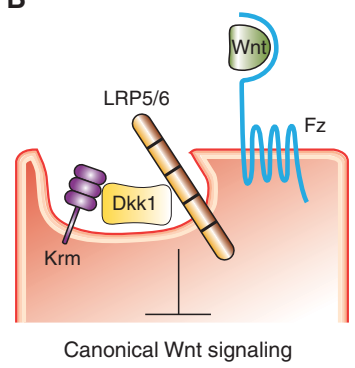

D

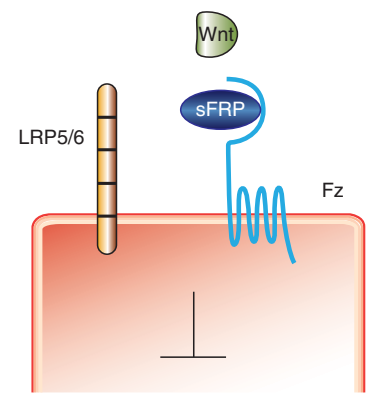

Canonical and noncanonical Wnt signaling

$\mathbf{F}$
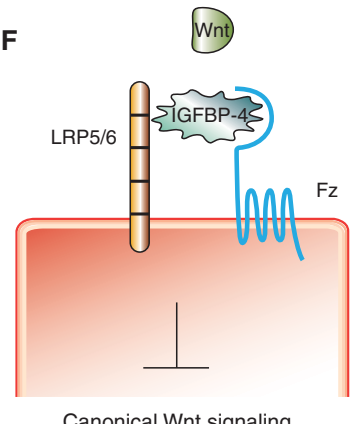

Figure 2. Models of Wnt signaling inhibition. $(A, B)$ Dkk1 binding to LRP6 disrupts the Wnt-induced Fz-LRP6 complex formation $(A)$ and/or induces LRP6 endocytosis in the presence of its coreceptor Kremen $(B) .(C)$ sFRPs, WIF-1, and Cerberus sequester Wnt, thereby inhibiting both canonical and noncanonical Wnt signaling. $(D)$ sFRPs may also inhibit canonical and noncanonical Wnt signaling by binding to Fz. (E) Wise/SOST binding to LRP6 blocks Wnt-induced Fz-LRP6 complex formation. (F) IGFBP-4 binds to LRP6 and Fz, thereby preventing signal transduction by Wnt.

In mouse embryos, $D k k 1$ is expressed from gastrula to neurula in the anterior visceral endoderm, anterior mesendoderm, and foregut endoderm, respectively, tissues which are all associated with anterior specification. Mice mutant for Dkk1 lack head structures anterior to the mid-hindbrain boundary, and already at embry- onic day 7.5 (E7.5) the anterior marker Hesx1 fails to be expressed (Mukhopadhyay et al. 2001). In the transgene-induced mouse mutant doubleridge, which harbors a hypomorphic $D k k 1$ allele $\left(D k k 1^{d}\right)$ with $10 \%$ normal expression levels, head development is normal. However, $D k k 1^{d /-}$ compound heterozygotes on a 


\section{C.-M. Cruciat and C. Niehrs}

Table 1. Mouse mutant phenotypes

\begin{tabular}{llc}
\hline Mouse mutant & \multicolumn{1}{c}{ Phenotype } & \multicolumn{1}{c}{ References } \\
\hline$D k k 1^{-/-}$ & $\begin{array}{l}\text { Embryonic lethal } \\
\text { Absence of anterior head structures } \\
\text { Postaxial polysyndactyly } \\
\text { Fused vertebrae }\end{array}$ & Mukhopadhyay et al. 2001 \\
& Viable and fertile \\
& Postaxial polysyndactyly & \\
$D k k 1^{d / d}$ & Viable and fertile & \\
$D k k 2^{-/-}$ & Osteopenia & MacDonald et al. 2004 \\
& Blindness, cornea transformation & \\
& Viable and fertile & Li et al. 2005a; \\
$D k k 3^{-/-}$ & Hyphopadhyay et al.
\end{tabular}

\section{Hyperactive}

Reduced lung ventilation and elevated hematocrit

Elevated IgM and natural killer cell levels

Sfrp1 $1^{-/-} \quad$ Viable and fertile

Normal and healthy

Sfrp $2^{-1-} \quad$ Viable and fertile

Sfrp $5^{-/-}$

$\operatorname{Sfrp1} 1^{-/-} / \operatorname{Sfrp} 2^{-/-}$

Wif- $1^{-/-}$

Wise $^{-/-}$

Sost $^{-/-}$

Cerl-1 $1^{-/-}$

$\operatorname{Igfb} 4^{-1-}$

Shisa ${ }^{-/-}$

Shisa $3^{-1-}$

Shisa $4^{-/-}$

Shisa $5^{-1-}$

Waif1 $/ 5 \mathrm{~T}^{-/+}$

Rspo1 $^{-/-} X X$
Hindlimb syndactyly at lower frequency

Viable and fertile

Normal and healthy

Embryonic lethal

Severe shortening of the thoracic region

Craniofacial defects

Limb outgrowth defects, extra digits

Defects in gonad morphology, gonad positioning, and reproductive tract maturation

Normal development

Susceptible to spontaneous and radiation-induced osteosarcoma

Viable and fertile

Defects in tooth development

Viable and fertile

Increased bone density, bone volume, bone formation, and bone strength

Viable and fertile

Viable and fertile

Modest growth deficit

Viable and fertile

Dwarf (in two-thirds of mutants)

Normal and fertile

Viable

Hydrocephalus

Viable

Partial sex-reversed phenotype

Masculinized features
Satoh et al. 2006

Satoh et al. 2006

Leaf et al. 2006; Satoh et al. 2006

Satoh et al. 2006; Warr et al. 2009

Kansara et al. 2009

Kassai et al. 2005; Yanagita et al. 2006; Ahn et al. 2010

Li et al. 2008a

Simpson et al. 1999; Belo et al. 2000; Shawlot et al. 2000; Stanley et al. 2000

Ning et al. 2006

Furushima et al. 2007

Furushima et al. 2007

Southgate et al. 2010

Chassot et al. 2008; Tomizuka et al. 2008 
Table 1. Continued

\begin{tabular}{llc}
\hline Mouse mutant & \multicolumn{1}{c}{ Phenotype } & References \\
\hline $\begin{array}{l}\text { Rspo2 } 2^{-/-} \\
\text {Rspo2 }^{\mathrm{Tg} / \mathrm{Tg}}\end{array}$ & Mortality & Nam et al. 2007a; Aoki \\
& $\begin{array}{l}\text { Defects: craniofacial, skeleton, limb, digits, tail, } \\
\text { renal, cardiovascular, respiratory, reproductive }\end{array}$ & et al. 2008; Bell et al. \\
& & 2008; Yamada et al. \\
Rspo3 $^{-/-}$ & Embryonic lethal & 2009; Jin et al. 2011 \\
& Defective angiogenesis in placenta and yolk sac $2007 ;$ \\
Norrin $^{-/-}$ & Abnormal vasculature in cochlea and retina & Kazanskaya et al. 2008 \\
& & Richter et al. 1998; Rehm \\
& & et al. 2002 \\
\hline
\end{tabular}

C57BL/6J genetic background show a variety of head defects, from hydrocephaly with micrognathia to loss of anterior head structures and eyes (MacDonald et al. 2004). Whereas Dkk1 heterozygous mice are normal and fertile, mice double heterozygous for $D k k 1$ and the BMP inhibitor Noggin show head defects similar to those of Dkk1 homozygous mutants (del Barco Barrantes et al. 2003), supporting the model that double inhibition of BMP and Wnt signals is required for head development (Glinka et al. 1997).

Dkk1 plays also a role in pregastrulation at E5.5-E6, when the initial proximal-distal axis of the mouse embryo is converted to AP polarity, by a process involving coordinated cell migrations (Kimura-Yoshida et al. 2005). Similarly, LRP5 $5^{-/} / L_{R P 6^{-/-}}$double mutants fail to induce and/or maintain the precursors of the primitive streak in the proximal epiblast of the pregastrula embryo (Kelly et al. 2004).

Role of Dkk1 in Limb, Bone, and Eye Formation. During early limb development, Wnt $/ \beta$ catenin signaling by Wnt3a is required for formation of the apical ectodermal ridge (AER), a signaling center that controls limb growth (Barrow et al. 2003; Soshnikova et al.2003). Similarly, overexpression of $D k k 1$ in chicks induces limb truncation, and this is accompanied by apoptosis (Mukhopadhyay et al. 2001; Grotewold and Ruther 2002). Conversely, overactivation of Wnt signaling by expression of a gain-of-function mutation of $\beta$-catenin results in expansion of the AER (Soshnikova et al. 2003). An expansion of the AER is observed in both Dkk1-null and hypomorphic $D k k 1^{d / d}$ mutants, suggesting a genetic interaction with Wnt3a (Mukhopadhyay et al. 2001; Adamska et al. 2004; MacDonald et al. 2004). In addition to AER expansion, $D k k 1$-null and $D k k 1^{d / d}$ mutants display postaxial polysyndactyly in the forelimbs (Mukhopadhyay et al. 2001; MacDonald et al. 2004), and normal digit numbers are restored in $D k k 1^{d / d} / L R P 6^{+j-}$ mice (MacDonald et al. 2004). Polydactyly in Dkk1 mutants can be reversed by the simultaneous loss of Wnt7a (Adamska et al. 2004). Thus, Dkk1 can control different steps involving Wnt3 or Wnt7a signaling during mouse limb development and digit patterning.

Wnt/ $\beta$-catenin signaling plays a central role in mammalian bone density regulation (Krishnan et al. 2006). Loss-of-function mutations of $L R P 5$ are associated with the recessive familial osteoporosis-pseudoglioma syndrome (Gong et al. 2001), whereas gain-of-function mutations of $L R P 5$ are associated with diseases of high bone mass (Boyden et al. 2002). Interestingly, for one particular LRP5 gain-of-function mutation, G171V, decreased inhibition of LRP5 by Dkk1 was suggested to account for increased LRP5 signaling (Boyden et al. 2002; Ai et al. 2005). Similar to humans, heterozygous $D k k 1^{+/-}$mice show an increase in bone mineral density (Morvan et al. 2006; MacDonald et al. 2007). Conversely, transgenic mice overexpressing Dkk1 in bone develop osteopenia (Li et al. 2006), suggesting that Dkk1 antagonizes Wnt-LRP5 signaling to regulate physiological levels of bone mass.

Wnt/ $\beta$-catenin signaling plays an important role during eye development, and Dkk1, -2 , and -3 are highly expressed in this organ (for details, see Niehrs 2006). The severity of head defects in Dkk1-null mutants precludes analysis of the role that Dkk1 may play in the 
developing eye. In contrast, Dkk2 knockout mice are viable, but blind, because of the development of a keratinized corneal epithelium and skin appendages as a result of constitutive Wnt/ $\beta$-catenin signaling in the cornea (Mukhopadhyay et al. 2006).

Dkks and Disease. A number of studies have implicated Dkk family members in human disease based on transcriptional profiling and epigenetic studies (for details, see Niehrs 2006). In particular, alterations of Dkk expression have been observed in a number of cancer models, which is not surprising given the importance of Wnt signaling in cancer biology. In colon cancer, for example, the observed epigenetic silencing of $D k k 1$ and other $D k k$ family genes is likely to contribute further to the activation of the Wnt/ $\beta$ catenin pathway (Aguilera et al. 2006; Sato et al. 2007). Dkk1 expression itself can be directly upregulated by $W n t / \beta$-catenin signaling in a T-cell factor (TCF)-dependent manner, but this mechanism appears to be lost through silencing in colon cancer (Gonzalez-Sancho et al. 2005).

Dkk1 has also been implicated in neurodegenerative processes and induction of apoptosis after neuronal injury (Caricasole et al. 2004; Cappuccio et al. 2005).

\section{sFRP Protein Family}

\section{Physical Properties and Structure}

The sFRPs represent the largest family of secreted Wnt inhibitors and resemble the ligand-binding CRD domain of the Frizzled family of Wnt receptors. The founding member of the family, Frzb (for Frizzled motif associated with bone development), was first purified as a chondrogenic factor from bovine cartilage extracts (Hoang et al. 1996). Shortly after, Frzb was isolated during a differential screen for cDNAs enriched in the Spemann organizer of Xenopus embryos (Bouwmeester et al. 1996) and shown to act as a Wnt antagonist (Leyns et al. 1997; Wang et al. 1997). Subsequently, additional members of the family were identified (Finch et al. 1997; Melkonyan et al. 1997; Rattner et al. 1997).

In humans, the sFRP family comprises five members, sFRP1-5, with sFRP3 being the or- tholog of Frzb, and orthologous genes have been identified in all vertebrates analyzed so far, as well as in invertebrates, but not in Drosophila (Bovolenta et al. 2008). On the basis of sequence homology and phylogenetic analysis, $s F R P 1,-2$, and -5 form a subgroup that diverges from the one formed by sFRP3 and -4 (Jones and Jomary 2002; Kawano and Kypta 2003; Bovolenta et al. 2008). This clustering also reflects a different genomic organization. Similar to human $D k k 1$, -2 , and $-4, s F R P 1,-2$, and -5 are located within the same chromosome 4/5/8/10 paralogy goup, whereas $s F R P 3$ and -4 are not part of this group. A third subgroup of sFRPs has been identified in Xenopus, chick, and zebrafish, but not in mammals. Members of this subgroup are Sizzled, Sizzled 2 , and Crescent, and they share sequence similarities with the $s F R P 1,-2$, and -5 subgroup (Pfeffer et al. 1997; Salic et al. 1997; Bradley et al. 2000; Pera and De Robertis 2000; Houart et al. 2002).

Human sFRPs consist of 295-346 amino acids and share at the amino terminus a CRD domain (Fig. 1). The CRDs of sFRPs show 30\%$50 \%$ sequence similarity with those of Fz receptors and contain 10 conserved cysteine residues (Rehn et al. 1998), which form a pattern of disulfide bridges (Chong et al. 2002). The carboxyterminal part of sFRPs contains a Netrin-related motif (NTR), which is found in a number of unrelated proteins, including the axon guidance protein netrin 1, tissue inhibitors of metalloproteinases (TIMPs), type-1 procollagen Cproteinase enhancer proteins (PCOLCEs), and complement proteins (Fig. 1) (Banyai and Patthy 1999). The NTR domain is characterized by segments of positively charged residues that appear to confer heparin-binding properties (Uren et al. 2000) and by six cysteine residues that form three disulfide bridges (Chong et al. 2002).

\section{Mechanism of Action}

Initial biochemical and functional analysis using Xenopus embryos and cultured cells showed that Frzb/sFRP3 binds to Wnt1 and XWnt8 and inhibits Wnt/ $\beta$-catenin signaling (Leyns et al. 1997; Lin et al. 1997; Wang et al. 1997). These results favor a model wherein sFRPs inhibit Wnt 
signaling by sequestering Wnts away from active receptor complexes (Fig. 2C). The CRD domain of Frzb seemed to be necessary and sufficient for both activities, Wnt binding and inhibition (Lin et al. 1997). In contrast, a mutant of sFRP1 lacking the CRD domain retained the ability to bind to Wingless, the Drosophila Wnt homo$\log$ (Uren et al. 2000). Another study of sFRP1 structure and function using Wnt reporter assays indicates that both protein domains, CRD and NTR, are important for optimal Wnt inhibition (Bhat et al. 2007). Furthermore, a recent study on sFRP1 combining biochemical and functional assays in cell culture and medakafish embryos shows that its NTR domain mimics the function of the entire molecule in binding Wnt8 and inhibiting Wnt signaling (Lopez-Rios et al. 2008). These conflicting results might imply that sFRPs have multiple Wntbinding sites and/or sFRP-Wnt pairs associate with different affinities. Indeed, whereas sFRP1 -4 have been shown to bind to Wnt3a with affinities in the nanomolar range, sFRP1 and -2 , but not sFRP3 and -4 , bound to Wnt5a. Moreover, only sFRP1 and -2 could block Wnt3a signaling in L cells (Wawrzak et al. 2007). Several other studies have described possible biochemical and/or functional specificity of the sFRPs-Wnt interactions in different developmental models, including the neural tube (Galli et al. 2006), somites (Lee et al. 2000), vascular endothelium (Dennis et al. 1999), and developing heart (Schneider and Mercola 2001), as well as during AP axial patterning of Xenopus embryos (Bradley et al. 2000; Pera and De Robertis 2000).

The crystal structures of the CRDs from mouse Fz8 and mouse sFRP3 have been determined and revealed the potential for the CRDs to dimerize (Dann et al. 2001). This possibility has been supported by the ability of sFRPs and Fz proteins to form homo- and heteromeric complexes through the CRD domain (Bafico et al. 1999; Rodriguez et al. 2005). These findings suggest an alternative model of how sFRPs could inhibit Wnt signaling, by forming nonfunctional complexes with Fz receptors (Fig. 2D).

Unlike Dkks, which specifically inhibit Wnt/ $\beta$-catenin signaling, sFRPs can also inhi- bit noncanonical Wnt/PCP ( planar cell polarity) signaling (Li et al. 2008b; Satoh et al. 2008; Matsuyama et al. 2009; Sugiyama et al. 2010), which is not surprising, as they bind to both types of Wnts. Inhibition of PCP signaling, which antagonizes $\mathrm{Wnt} / \beta$-catenin signaling (Yan et al. 2001; Schwarz-Romond et al. 2002; Simons et al. 2005; Li et al. 2011), may also explain why sFRPs can activate $\mathrm{Wnt} / \beta$-catenin signaling (Swain et al. 2005). Interestingly, in Xenopus, Frzb and Crescent can activate canonical Wnt signaling by promoting the diffusion of Wnt8 and Wnt11 (Mii and Taira 2009). In addition to Wnt signaling, sFRPs can regulate other signaling cascades. sFRP1, for example, binds to RANKL, a member of the tumor necrosis factor family, thereby inhibiting osteoclast formation (Hausler et al. 2004). sFRP1 also interacts with and inhibits the metalloprotease ADAM10, thus acting as a negative modulator of Notch signaling to regulate retinal neurogenesis (Esteve et al. 2011). Sizzled binds to and inhibits the activity of BMP1/Tolloid, a metalloprotease that cleaves the BMP antagonist chordin, thereby inhibiting BMP signaling (Lee et al. 2006).

\section{Role of sFRPs in Embryonic Development and Pathological Events}

The expression pattern of several sFRPs has been analyzed in different developmental systems, including medaka fish, Xenopus, chick, and mouse embryos (for details, refer to Jones and Jomary 2002; Bovolenta et al. 2008). sFRPs show a dynamic, partly overlapping, but also distinct expression pattern. To examine their roles in embryogenesis, single Sfrp1, Sfrp2, and Sfrp5 knockout mice (Leaf et al. 2006; Satoh et al. 2006), as well as different combinations of double- and triple-mutant mouse lines carrying homozygous or heterozygous mutations of two or all three genes, have been generated (Table 1) (Satoh et al. 2008). Apart from Sfrp1 $1^{-/} /$ Sfrp2 $2^{-1-}$ double-mutant and Sfrp1 $1^{-/}$ Sfrp $2^{-/-} /$Sfrp $5^{-/-}$triple-mutant mice, the other mutant mice are viable and fertile and have no obvious abnormalities in gross morphology, indicative of the redundant role of Sfrps 
in embryonic development. In contrast, inactivation of Sfrp1 plus Sfrp2 is embryonic lethal as a result of severe shortening of the AP axis and incomplete somite segmentation, and this phenotype becomes more severe when Sfrp5 is also inactivated. Genetic analysis combining Sfrp triple-knockout mice and Loop-tail mice, which carry a mutation in Stbm/Vangl2, revealed the involvement of sFRPs in convergent extension through the regulation of the PCP pathway ( $\mathrm{Sa}$ toh et al. 2008). In addition, Dkk1-deficient embryos carrying Sfrp1 homozygous and Sfrp2 heterozygous mutations display irregular somites and indistinct intersomitic boundaries, indicating that sFRP-mediated inhibition of $\mathrm{Wnt} / \beta$ catenin signaling is required for somitogenesis (Satoh et al. 2008).

In addition to the role in regulating $\mathrm{AP}$-axis elongation and somitogenesis during mouse development, Sfrp1 and -2 exert redundant roles also in embryonic organogenesis, as both genes are required for normal male sexual development in mice (Warr et al. 2009).

In line with their function as Wnt signaling antagonists, sFRPs appear to act as tumor suppressor genes, as loss or down-regulation of sFRP expression has been observed in a variety of invasive carcinomas. Epigenetic silencing of sFRP1 and -2 by hypermethylation seems to occur in basically all tumor types, and the sFRP1 promoter methylation status has been proposed to serve as a biomarker for cancer detection and progression (for details, see Bovolenta et al. 2008; Esteve and Bovolenta 2010). sFRPs are also implicated in other pathological events, such as osteolysis and heterotopic ossification (Gordon et al. 2007) and during photoreceptor degeneration (Hackam 2005).

\section{WIF-1}

Wnt-inhibitory factor 1 was first identified as an expressed sequence tag from the human retina (Hsieh et al. 1999), and is present in fish, amphibians, and mammals. Wif- 1 is expressed in a variety of tissues, being most abundant in brain, lung, retina, and cartilage (Hsieh et al. 1999; Hunter et al. 2004; Hu et al. 2008; SurmannSchmitt et al. 2009). WIF-1 is a protein of 379 amino acids with a unique and highly conserved WIF domain, five EGF-like repeats, and a hydrophilic tail (Fig. 1). Interestingly, the WIF domain is also found in the extracellular domain of RYK receptor tyrosine kinase. The phenotype induced by overexpression of WIF-1 in Xenopus embryos, namely, induction of a secondary axis and abnormal somitogenesis, together with its ability to block XWnt8 activity, suggested it plays a role in Wnt signaling (Hsieh et al. 1999). Indeed, WIF-1 binds to XWnt8 and Wingless and inhibits the interaction between XWnt8 and Drosophila Fz2 (Hsieh et al. 1999). This result suggests that similar to sFRPs, WIF-1 prevents Wnt from binding to its receptors, thus affecting canonical and noncanonical pathways (Fig. 2C). Recently, WIF-1 has been shown to bind to both types of Wnts, canonical and noncanonical, including Wnt3a, Wnt4, Wnt5a, Wnt7a, Wnt9a, and Wnt11, and to regulate Wnt activity during cartilage development (Surmann-Schmitt et al. 2009).

The mechanism of how WIF-1 regulates Wnt signaling is not completely understood, but the observed silencing of WIF-1 in different tumors suggests that like Dkks and sFRPs, this secreted factor plays an important role in cancer and other biological processes related to Wnt signaling (Chien et al. 2009; Kansara et al. 2009; Elston and Clifton-Bligh 2010).

\section{Wise and SOST}

Wise, also known as SOSTDC1 (sclerostin domain-containing 1), Ectodin, and USAG-1 (uterine sensitization-associated gene-1), has been isolated by a functional screen for activities that alter the AP character of neuralized Xenopus tissues (Itasaki et al. 2003). Sequence and structural analysis revealed that Wise forms a cystine knot (Ellies et al. 2006; Lintern et al. 2009) and belongs together with SOST to the CAN subfamily of cystine knot-containing BMP antagonists (Avsian-Kretchmer and Hsueh 2004). In Xenopus Wise appears to be a contextdependent regulator of Wnt signaling; it may inhibit or activate Wnt signaling in different assays (Itasaki et al. 2003). In cell culture Wise blocks Wnt1 and Wnt3a activities in reporter 
assays (Yanagita et al. 2004; Blish et al. 2008). It interacts with LRP6 through one of the three loops formed by the cystine knot (Lintern et al. 2009) and is able to compete with Wnt8 for binding to LRP6 (Fig. 2E) (Itasaki et al. 2003). Not only secreted Wise is able to inhibit Wnt signaling, but endoplasmic reticulum (ER)-retained Wise is also able to do so by reducing cell surface LRP6 (Guidato and Itasaki 2007). Wise also binds the LRP4 receptor (Ohazama et al. 2008), which is able to modulate Wnt signaling mediated by LRP5 and -6 (Ohazama et al. 2008; Li et al. 2010).

Wise is expressed in various tissues, including the surface ectoderm of the posterior axis, branchial arches, dermal papilla in hair follicles, vibrissae, tooth cusps, rat endometrium, developing testis, and kidney (Lintern et al. 2009). Wise-null mice are viable and fertile and apparently healthy, except that they exhibit tooth abnormalities, including supernumerary incisors and molars, fused molars, and cusp defects (Table 1) (Kassai et al. 2005; Yanagita et al. 2006; Ahn et al. 2010). This abnormal tooth development seems to be caused by elevated Wnt $/ \beta$-catenin signaling. Indeed, in Wise $e^{-/-} / \mathrm{LRP}^{-/-} /$ $L P 6^{+/-}$triple-mutant mice, most of the different tooth defects of Wise-null mutants are rescued, indicating that inhibition of Wnt/ $\beta$-catenin by Wise controls tooth development (Ahn et al. 2010).

Wise shares 38\% identity and a cystine knot domain with SOST (Fig. 1). SOST is highly expressed in osteoblasts and osteocytes, and loss-offunction mutations or down-regulation of SOST are responsible for two rare forms of autosomal recessive severe craniotubular hyperostoses, sclerosteosis (Balemans et al. 2001; Brunkow et al. 2001), and van Buchem disease (Balemans et al. 2002; Staehling-Hampton et al. 2002), which are characterized by overgrowth of bone tissue. Similarly, SOST-null mutant mice have a high-bonemass phenotype characterized by increase in bone mass density, bone volume, bone formation, and bone strength (Table 1) (Li et al. 2008a).

SOST antagonizes Wnt signaling by binding to the first two YWTD-EGF repeat domains of LRP5 and LRP6 (Li et al. 2005b; Semenov et al. 2005). Like Dkk1, SOST has the ability to disrupt
Wnt1-induced Fz8-LRP6 complex formation, suggesting a potential mechanism of action (Fig. 2E) (Semenovet al.2005). Thus, the loss of SOST function likely leads to the hyperactivation of Wnt signaling that underlies bone overgrowth seen in sclerosteosis patients. Interestingly, sclerosteosis shares remarkable similarities with diseases of high bone mass caused by gain-of-function mutations in the LRP5 gene, such as the G171V point mutation (Boyden et al. 2002; Little et al. 2002), and this mutation as well as an analogous mutation in LRP6 (G158V) blocks binding of SOST to LRP5 and LRP6 (Ellies et al. 2006; Semenov and He 2006). Evidence for a genetic interaction between SOST and LRP6 is provided by rescue experiments. In SOST ${ }^{-/-} /$LRP6 $^{-/-}$double-mutant mice, the hand and foot defects observed in $\mathrm{LRP}^{-/-}$ mutant mice are rescued (Collette et al. 2010).

Wise and SOST belong to a subfamily of cystine knot-containing proteins, members of which inhibit BMP signaling (Avsian-Kretchmer and Hsueh 2004). In cell culture models Wise and SOST inhibit BMP signaling (Laurikkala et al. 2003; Winkler et al. 2003); however, the physiological role of this inhibition is still unclear.

\section{Cerberus}

Cerberus was isolated from Xenopus as an abundant organizer-specific gene, capable of inducing ectopic heads, when overexpressed in Xenopus embryos (Bouwmeester et al. 1996). Cerberus-related proteins have been identified in other vertebrates, such as zebrafish, chick, and mouse (Belo et al. 2009). They share a cystine knot domain at the carboxyl terminus (Fig. 1) and undergo proteolytic cleavage after secretion (Piccolo et al. 1999). Xenopus Cerberus binds to Nodal, BMP, and Wnt proteins via independent sites and inhibits all three signaling pathways, which leads to simultaneous head formation and trunk inhibition (Piccolo et al. 1999). Conversely, Morpholino-mediated knockdown of Cerberus in Xenopus embryos impairs head induction (Silva et al. 2003; Kuroda et al. 2004).

Unlike its Xenopus counterpart, mouse Cerl-1 does not bind Wnt and inhibit Wnt 
signaling (Belo et al. 2000) and is not essential for mouse head formation (Table 1) (Simpson et al. 1999; Belo et al. 2000; Shawlot et al. 2000; Stanley et al. 2000). Rather, Cerberus-related proteins are key regulators of Nodal signaling and play an important role in the establishment of left-right asymmetry in the vertebrate embryo (Rodriguez Esteban et al. 1999; Yokouchi et al. 1999; Zhu et al. 1999; Hashimoto et al. 2004; Marques et al. 2004; Tavares et al. 2007; Vonica and Brivanlou 2007).

\section{IGFBP-4}

IGFBP-4 belongs to the family of insulin-like growth factor binding proteins (IGFBPs), which modulate the actions of insulin-like growth factors (IGFs) (Firth and Baxter 2002). IGFBP-4 was identified in a screen for factors able to induce cardiomyocyte differentiation of P19CL6 cells (Zhu et al. 2008a). It promotes cardiogenesis in an IGF-independent fashion, namely, by antagonizing $\mathrm{Wnt} / \beta$-catenin signaling (Zhu et al. 2008a). It binds directly to LRP6 and Fz8 via the carboxy-terminal thyroglobulin domain and blocks binding of Wnt3a to the receptors (Fig. 2F). Morpholino-mediated knockdown of IGFBP-4 in Xenopus embryos leads to cardiac defects, similar to those induced by overexpression of XWnt8. These defects were rescued by coexpression of a dominant-negative form of LRP6, suggesting that the cardiogenic effect of IGFBP-4 is mediated by inhibition of $\mathrm{Wnt} / \beta$ catenin signaling.

Of the six IGFBP protein family members, IGFBP-1, -2 , and -6 , but not IGFBP-3 and -5, are also able to bind directly to LRP6 and Fz8 and to inhibit Wnt/ $\beta$-catenin signaling, albeit with a lower efficiency compared with IGFBP-4 (Zhu et al. 2008a). Thus, the lack of cardiac phenotypes in $I g f b$-4-null mice or $I g f b-3,-4$, and -5 triple-knockout mice (Ning et al. 2006) may be caused by genetic redundancies between IGFBP-4 and other IGFBPs.

IGFBP-4-mediated inhibition of $\mathrm{Wnt} / \beta$ catenin signaling might have some implications for cancer biology. Treatment with IGFBP-4 reduces cell proliferation in some cancer cell lines in vitro, and overexpression of IGFBP-4 atten- uates the growth of prostate cancer in vivo (Durai et al. 2006).

\section{TRANSMEMBRANE WNT INHIBITORS}

\section{Shisa Protein Family}

The Shisa protein family comprises five subfamilies in vertebrates (Furushima et al. 2007). Recently, in a search for sequence similarity to Shisa proteins, four additional subfamilies were found in vertebrates (Pei and Grishin 2012). Shisa proteins share a signal peptide, an amino-terminal CRD, a predicted transmembrane segment, and a carboxy-terminal proline-rich region (Fig. 1) (Pei and Grishin 2012).

The founding member of this family, Xenopus Shisa1, was identified as a gene specifically expressed in the prospective head ectoderm and the Spemann organizer (Yamamoto et al. 2005). In Xenopus embryos, overexpressed Shisal expands anterior neural structures, and together with a BMP inhibitor induces a secondary head. Conversely, knockdown of Shisal by Morpholino injection in Xenopus embryos suppresses anterior neural marker expression and head structures, indicating a requirement for head formation. Shisal does not inhibit BMP and Nodal signaling, but functions in head formation as an inhibitor of Wnt and fibroblast growth factor (FGF) signaling. It functions cell-autonomously in the ER, where it traps Fz and the FGF receptor and prevents their maturation (Yamamoto et al. 2005).

In Xenopus, three paralogous genes to XShisal were identified: XShisa2, -3, and -4 (Nagano et al. 2006; Silva et al. 2006). XShisa2 is expressed in somitic mesoderm and like Shisa1 inhibits both Wnt and FGF signaling, thereby regulating segmental patterning during somitogenesis (Nagano et al. 2006). Shisa homologs were also reported in zebrafish, rat, mouse, chicken, and human (Katoh and Katoh 2005; Furushima et al. 2007; Hedge and Mason 2008; Zhu et al. 2008b).

In mouse, four Shisa family members are present: mShisa and mShisa3, -4, and -5 (Furushima et al. 2007). The expression of mShisa is similar to that of XShisal and -2. It is expressed 
in anterior visceral endoderm, anterior mesendoderm, anterior neuroectoderm, and somitic mesoderm (Furushima et al. 2007). Like XShisal and -2, overexpressed mShisa inhibits Wnt signaling in Xenopus and mammalian cells. However, mShisa $^{-/-}$mutant mice had no phenotype in either head development or somitogenesis, and double-knockout mutants of mShisa with mShisa3, -4 , or -5 displayed no additional phenotype (Furushima et al. 2007). These results suggest that Shisa loss-of-function in mouse head and somites development may be compensated by other Wnt antagonists, such as Dkk, sFRP, and Cerberus.

\section{Waif1/5T4}

Waifla was identified in gene expression profiling of zebrafish embryos as a novel direct Wnt/ $\beta$-catenin target and functionally characterized in zebrafish, Xenopus, mouse, and mammalian cells (Kagermeier-Schenk et al. 2011). Waifla is a single-pass plasma membrane protein with several leucine-rich repeats in the extracellular part and a short carboxyl terminus without conserved motifs (Fig. 1). In zebrafish and Xenopus, Waif1a is expressed during early embryogenesis in regions of active $\mathrm{Wnt} / \beta$-catenin signaling, in particular the dorsolateral marginal epiblast during gastrulation, and its expression is directly regulated by Wnt8. Waifla inhibits Wnt/ $\beta$-catenin signaling in zebrafish and Xenopus. Likewise, mouse and human Waif1/5T4 antagonizes Wnt signaling in cultured cells. Zebrafish Waifla acts as a direct feedback inhibitor of Wnt8-mediated mesoderm and neuroectoderm patterning during zebrafish gastrulation. At the molecular level Waifla binds to LRP6 and inhibits both Wnt3a- and Dkk1-induced LRP6 internalization without affecting Wnt3a-induced LRP6 phosphorylation, by a mechanism that needs further elucidation. At the same time Waifla activates noncanonical Wnt/PCP signaling in zebrafish embryos and Xenopus explants by promoting the ability of Dkk1 to activate Wnt/PCP signaling.

The elevated expression of Waif1/5T4 in human carcinomas, which correlates with poor survival prognosis, highlights its relevant role in cancer biology (Starzynska et al. 1994; Naganuma et al. 2002).

\section{APCDD1}

Adenomatosis polyposis coli down-regulated 1 (APCDD1) was initially isolated in a search for genes that were down-regulated after induction of APC in SW480 colon cancer cells (Takahashi et al. 2002). APCDD1 is a membrane-bound glycoprotein, conserved throughout vertebrate evolution. In mouse embryos, APCDD1 is expressed in the nervous and vascular system, the inner ear, and the mesenchyme of several developing organs (Jukkola et al. 2004). Abundant expression of APCDD1 is observed in mouse and human hair follicles (Jukkola et al. 2004; Shimomura et al. 2010). A point mutation (L9R) in APCDD1 causes hereditary hypotrichosis simplex, a rare autosomal dominant form of hair loss (Shimomura et al. 2010). This mutation is located in the signal sequence and impairs protein transport to the plasma membrane. The finding that APCDD1 is a direct Wnt/ $\beta$-catenin target (Takahashi et al. 2002), and its similarity in expression with Wise (O’Shaughnessy et al. 2004), encouraged Shimomura et al. to analyze if APCDD1 may function as a Wnt inhibitor. They found that soluble APCDD1 binds to Wnt3a and to the extracellular domain of LRP5 in vitro, and it inhibits Wnt/ $\beta$-catenin signaling in cultured cells, possibly by preventing $\mathrm{Fz}$ from binding to Wnt. In vivo, APCDD1 inhibits Wnt signaling during the generation of neurons from progenitors in the developing chick nervous system and during axis specification in Xenopus embryos. Given its broad expression in various cell types, APCDD1 may regulate several other biological processes controlled by Wnt signaling.

\section{Tiki1}

Tikil was identified by functional cDNA screening as an organizer-specific gene, required for anterior neural development in Xenopus (Zhang et al. 2012). Tikil encodes an evolutionary conserved transmembrane metalloprotease that inhibits Wnt signaling by removing eight 
amino-terminal residues from Wnt itself, thereby leading to formation of oxidized Wnt oligomers with impaired receptor-binding capability (Zhang et al. 2012).

\section{WNT ACTIVATORS}

\section{R-Spondin Protein Family}

\section{Physical Properties and Structure}

R-Spondins (Rspo1 to -4) are a small family of four secreted growth factors, which in addition to Wnts potently activate $\beta$-catenin signaling. The first identified member of this family was human R-spondin 3 (Chen et al. 2002). Subsequently, mouse $R$-spondin1 (roof plate-specific spondin) was discovered as a gene specifically expressed in the roof plate of the neural tube and the dorsal part of telencephalon (Kamata et al. 2004), and Xenopus $R$-spondin2 was isolated in a functional screen for its property to activate $\mathrm{Wnt} / \beta$-catenin signaling (Kazanskaya et al. 2004). Rspos are evolutionarily conserved and are present also in invertebrates, such as hemichordates, chordates, and echinoderms, but not in Drosophila and C. elegans (Kim et al. 2006; Yoon and Lee 2012). In mammals, Rspol to -4 show about $60 \%$ overall sequence homology and share a signal peptide, two amino-terminal furinlike CRDs, followed by a thrombospondin type- 1 domain and a positively charged carboxy-terminal region (Fig. 1) (Kazanskaya et al. 2004).

Although Rspos contain an amino-terminal signal peptide, secreted proteins are barely detectable in the medium of transfected cells (Kazanskaya et al. 2004). Treatment of cells with soluble heparin or sodium chlorate, an inhibitor of sulfation, increases the level of Rspo proteins in the conditioned medium, suggesting that Rspos may bind to heparin sulfate proteoglycans, including syndecans and glypicans (Nam et al. 2006). Indeed, Rspo3 binds syndecan 4 (Sdc4) (Ohkawara et al. 2011) (see below).

\section{Mechanism of Action}

The characteristic feature of all four Rspos is their ability to activate canonical Wnt signaling. Rspos synergize with Wnts (Kazanskaya et al.
2004; Kim et al. 2005; Nam et al. 2006; Wei et al. 2007; Kim et al. 2008) and require the presence of Wnts to activate $\beta$-catenin signaling (Binnerts et al. 2007). The precise mechanism of Rspo-driven $\beta$-catenin activation is poorly understood, yet recent discoveries started to shed light on it.

For a couple of years the Rspo receptor turned out to be a matter of controversy. Initially, it was suggested that Rspos bind to Fz8 (Nam et al. 2006), but this interaction was not confirmed (Wei et al. 2007; Ohkawara et al. 2011). In another study Kremen was reported to bind Rspo1 (Binnerts et al. 2007), but this interaction may not be physiologically relevant, because Kremen1 and -2 double-knockout mice are viable, unlike most Rspo single-mutant mice, and fibroblasts isolated from these Kremen-deficient mice respond normally to Rspo (Ellwanger et al. 2008). Alternatively, LRP6 has been proposed as Rspo receptor (Wei et al. 2007), but this interaction also was not confirmed by others (Binnerts et al. 2007; Glinka et al. 2011). Of note, none of these studies addressed whether Fz8, LRP6, or Kremen was required for Rspo signaling.

Recently, several groups showed that the leucine-rich repeat containing G-protein-coupled receptor 5 (LGR5) and its homolog LGR4 are Rspo receptors. LGR5 marks proliferative stem cells in several Wnt-dependent compartments, such as small intestine, colon, stomach, and hair follicle, whereas LGR4 expression is much broader (Barker and Clevers 2010). LGR4 and -5 are required for Rspo signaling, and they synergize with Rspo and Wnt3a in Wnt/ $\beta$-catenin signaling. Rspol to -4 bind with high affinity to LGR4 and -5 and their apparent $K_{\mathrm{d}}$ was determined to be in the nanomolar range (Carmon et al. 2011; de Lau et al. 2011; Glinka et al. 2011). Both Rspo binding to LGR4/5 and its function are mediated by the furin domains (Kazanskaya et al. 2004; Glinka et al. 2011). Moreover, Rspo3-LGR4 signaling requires clathrin-mediated endocytosis, which is essential for $\beta$ catenin activation (Glinka et al. 2011). Requirement of Rspo1/Wnt3a-induced clathrin-mediated endocytosis of LGR5 for Wnt/ $\beta$-catenin signaling was not observed by others (Carmon 
et al.2012), which might be due to artificial overexpression of LGR5 together with LRP6 and Fz5.

What is the mechanism by which Rspo and LGR $4 / 5$ potentiate $\mathrm{Wnt} / \beta$-catenin signaling? Cong and his coworkers provide insight into this mechanism. In a search for novel negative Wnt regulators, they identified transmembrane E3 ubiquitin ligase ZNRF3 and its homolog ring finger 43 (RNF43) (Hao et al. 2012). ZNRF3 inhibits Wnt signaling by promoting the turnover of Fz receptors and LRP6. Rspo binds to the extracellular part of ZNRF3 and promotes the interaction between ZNRF3 and LGR4, which results in ZNRF3 clearance from the membrane. These results suggest a model wherein Rspo activates Wnt signaling by inhibiting ZNRF3 in an LGR4-dependent manner, resulting in the accumulation of Wnt receptors at the cell surface (Fig. 3A). The ZNRF3-mediated suppression of Wnt $/ \beta$-catenin signaling is crucial for lens development in mice (Hao et al. 2012).

Apart from their function in canonical Wnt signaling, Rspos also amplify Wnt/PCP signaling. In particular, Rspo3 binds Sdc4 through its thrombospondin type-1 domain, and they functionally interact during Xenopus gastrulation and head cartilage morphogenesis, two
A

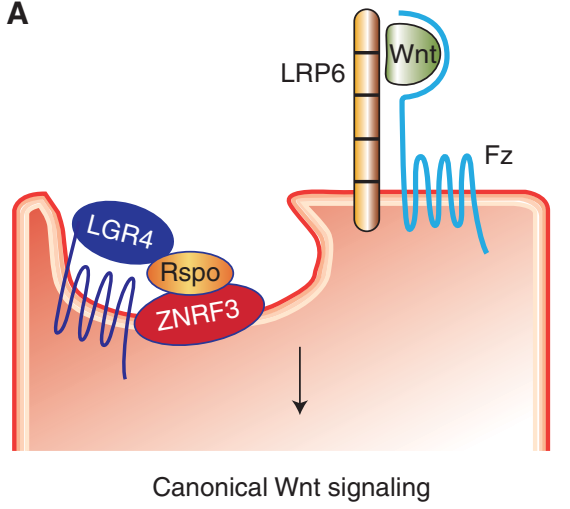

B

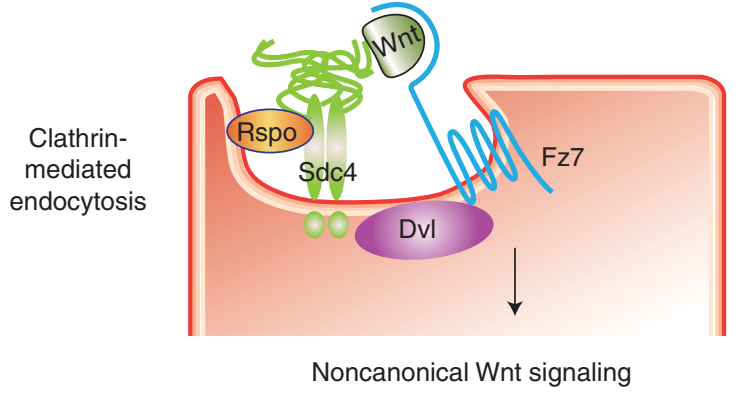

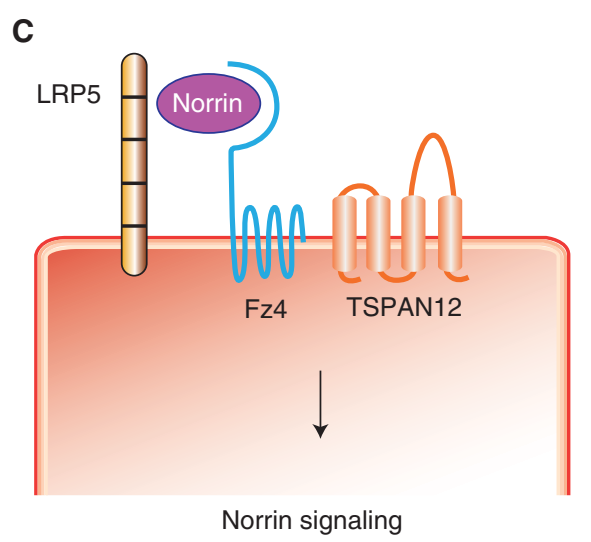

Figure 3. Models of Wnt signaling activation. (A) Rspo binds to ZNRF3 and LGR4 and induces clathrinmediated receptor endocytosis. Internalized ZNRF3 is unable to ubiquitinate and target Wnt receptors for degradation. As a consequence, Fz and LRP6 accumulate on the plasma membrane and transmit canonical Wnt signals. (B) Rspo3 binding to Sdc4 promotes clathrin-mediated endocytosis of the Wnt receptor complex and thereby activates noncanonical Wnt signaling. $(C)$ TSPAN12 is part of the Norrin/Fz4/LRP5 signaling complex and promotes Norrin $/ \beta$-catenin signaling. 
Wnt/PCP-driven processes (Ohkawara et al. 2011). Rspo3/Sdc4 signaling requires Wnt5a, Fz7, and Dvl and activates JNK (Ohkawara et al. 2011). Moreover, Rspo3 binding to Sdc4 promotes clathrin-mediated endocytosis, which is essential for PCP signal transduction (Fig. 3B). Not surprisingly, LGR4/5 are also essential for Rspo3-induced Wnt/PCP signaling in Xenopus (Glinka et al. 2011), and the interaction of ZNRF3 with Rspo and LGR4 suggests that this complex functions in Wnt/PCP signaling as well. Further studies are needed to clarify the interplay between Rspo/Sdc4 and Rspo/LGR/ ZNRF3 in PCP signaling, and to determine the factor(s) that confer specificity of Rspo to signal either by $\beta$-catenin or the PCP pathway.

\section{Role of Rspos in Embryonic Development and Disease}

Loss-of-function analyses in Xenopus and mice as well as recent genetic studies in humans underline the role of Rspos in embryonic development and disease. In Xenopus and mouse, Rspo family members show differential expression in a broad range of embryonic tissues, such as dorsal neural tube, somites, tailbud, AER of the limb, and developing brain (Kazanskaya et al. 2004; Nam et al. 2007b). They are coexpressed with several Wnt genes and their expression is regulated by Wnts (Kazanskaya et al. 2004).

Role of Rspo1 in Female Sex Determination. Mutations in human Rspol were identified in individuals with female-to-male sex reversal (Parma et al. 2006) or XX true hermaphroditism (Tomaselli et al. 2008), a disorder of gonadal development characterized by the presence of both ovarian and testicular tissue. These mutations result either in a stop codon immediately after the signal peptide or in a truncated protein lacking the first furinlike domain, and thus are linked to the inability of Rspol to activate Wnt signaling. The potential role of Rspol as a candidate female-determining gene is confirmed in Rspo 1 knockout XX mice, which display masculinized ovaries (ovotestis) with epididymis and vas deferens-like structures (Chassot et al. 2008; Tomizuka et al. 2008). The observed reduction of Wnt4 expression and the impaired Wnt/ $\beta$ catenin activity in these mice, as well as the sex reversal phenotype observed in $\mathrm{Wnt4}^{-/-}$animals (Vainio et al. 1999), suggest a crucial role for Rspo1/Wnt4/ $\beta$-catenin signaling in ovary development.

Mutations in human Rspol are also responsible for palmoplantar hyperkeratosis and predisposition to squamous cell carcinoma of the skin (Parma et al. 2006), suggesting that Rspol might act as a tumor suppressor gene. Indeed, suppression of Rspol expression by hypermethylation of its promoter is found in leukemia cell lines and leukemia patients (Kuang et al. 2008).

Role of Rspo2 in Limb, Craniofacial, and Lung Morphogenesis and Myogenesis. Footless is a mouse mutant carrying a hypomorphic allele of Rspo2 (Rspo2 $2^{T g / T g}$ ) (Bell et al. 2008). Rspo2 knockout mice were generated (Nam et al. 2007a; Aoki et al. 2008; Bell et al. 2008; Yamada et al. 2009; Jin et al. 2011). All these animals immediately die after birth and display hindlimb defects, severe laryngeal and tracheal malformations, lung hypoplasia, and branching defects. In particular, abnormal limb development is manifested through a delayed maturation of the AER. Expression of Axin2 and the TopGAL transgene is significantly reduced in the AER of Rspo 2 mutant mice, indicating that Rspo 2 activity in the AER is mediated by Wnt/ $\beta$-catenin signaling (Nam et al. 2007a; Bell et al. 2008). Furthermore, double-knockout mutants of Rspo2 and LRP6 (Rspo2 $2^{T g / T g} / \mathrm{LRP}^{-/-}$) showed much more severe limb defects than the single-knockouts, indicating that both genes functionally interact to regulate limb development (Bell et al. 2008).

In Xenopus, Rspo 2 through Wnt/ $\beta$-catenin signaling is required for the expression of myogenic marker genes, myf5 and myoD, and later muscle development (Kazanskaya et al. 2004). Consistently, limb-specific myf5 expression is down-regulated in Rspo2 knockout mice (Han et al. 2011), supporting a role of Rspo2 in myogenesis.

Role of Rspo3 in Vasculogenesis and Angiogenesis. In Xenopus embryos, Rspo3 regulates the balance between hematopoietic and endo- 
thelial differentiation by promoting angioblast specification and inhibiting blood cell specification. It does so by promoting $\mathrm{Wnt} / \beta$-catenin signaling, which is required for expression of VEGF (Kazanskaya et al. 2008). In mice, targeted deletion of Rspo3 is embryonic lethal because of angiogenesis defects in placenta and yolk sac (Aoki et al. 2007; Kazanskaya et al. 2008). As in Xenopus, mouse Rspo3 is required for Wnt/ $\beta$-catenin-mediated induction of vascular endothelial growth factor (VEGF). Moreover, recombinant Rspo3 promotes proliferation and angiogenesis in endothelial cell lines (Kazanskaya et al. 2008).

Role of Rspo4 in Nail Development. Mutations in Rspo4 cause anonychia (Bergmann et al. 2006; Blaydon et al. 2006; Bruchle et al. 2008; Ishii et al. 2008), an autosomal recessive disorder characterized by partial or complete loss of finger- and toenails (Baran and Kechijian 2001). Rspo4 mutations are found either in the furinlike domains, or predict truncated versions lacking any feature of an Rspo protein.

Role of Rspos in Cancer. In addition to the possible role of Rspol as tumor suppressor, Rspo 2 and -3 promote tumorigenesis in vivo. Rspo 2 was identified as a common integration site for the mouse mammary tumor virus (MMTV) in mouse mammary tumors (Lowther et al. 2005), as well as a candidate colorectal cancer gene (Starr et al. 2009). In a similar screen for MMTV insertion sites, Rspo3 was identified as a candidate breast cancer gene, which can strongly enhance oncogenicity (Theodorou et al. 2007).

\section{Norrin}

The Norrie disease pseudoglioma (NDP) or Norrin gene encodes a small secreted factor containing a cystine knot motif (Fig. 1) and a tertiary structure similar to that of TGF- $\beta$ (Meitinger et al. 1993). Mutations in Norrin cause Norrie disease (Berger et al. 1992; Chen et al. 1992; Meindl et al. 1992), an X-linked disorder characterized by vascular abnormalities in the eye and blindness, often accompanied by progressive hearing loss and mental retardation (Berger 1998).
The nearly identical vascular defects in the retina and inner ear observed in $\mathrm{Fz}^{-/-}$mice (Xu et al. 2004) and in $N d p$ knockout mice (Richter et al. 1998; Rehm et al. 2002) encouraged Nathans and his coworkers to analyze whether Norrin and Fz4 constitute a ligandreceptor pair. Indeed, Norrin is a high-affinity ligand for Fz4. It binds to the CRD of Fz4 with nanomolar affinity and cooperates with Fz4 to activate lymphoid enhancer factor (LEF)/TCFmediated transcription in an LRP5/6-dependent manner (Xu et al. 2004). Thus, although structurally unrelated to Wnts, Norrin functions like a Wnt. Norrin function requires three pairs of cysteines that form the conserved trio of disulfide bonds shared among all cystine knot proteins (Smallwood et al. 2007).

Evidence for a functional interaction between Norrin, Fz4, and LRP5 in vivo is provided by the finding that in humans, mutations in each gene cause familial exudative vitreoretinopathy (Chen et al. 1993; Robitaille et al. 2002; Toomes et al. 2004a,b), an inherited disease characterized by peripheral retinal avascularity (Warden et al. 2007). Consistent with the findings in human patients, targeted inactivation of Norrin, Fz4, or LRP5 in mice causes similar alterations in the retinal vascularization (Xu et al. 2004; Luhmann et al. 2005a; Xia et al. 2008).

Among the 10 mammalian Fzs, Fz4 is the only Norrin receptor (Smallwood et al. 2007). Yet Fz4 can also transduce the signal of Wnts, raising the question of how Fz4/LRP5 can respond to different types of ligands to activate $\beta$-catenin-dependent transcription. The identification of TSPAN12, a tetraspanin family member, as a component of the Norrin/Fz4/ LRP5 complex provides an answer to this question. TSPAN12 specifically promotes Fz4/LRP5 signaling induced by Norrin, but not by Wnt ligands, to regulate retinal vascular development in mice (Fig. 3C) (Junge et al. 2009).

The expression of mouse Norrin in the developing retina, neural tube, and brain and its expression in the adult central nervous system, uterus, and decidua (Luhmann et al. 2005b; Ye et al. 2011) suggest that Norrin may have developmental functions beyond those described in the eye. 


\section{CONCLUDING REMARKS}

Considerable progress has been made in our effort to understand the molecular mechanism by which Wnt inhibitors and activators regulate Wnt signaling. These molecules have emerged as key regulators of Wnt signaling-controlled processes during embryogenesis, including head, limb, bone, heart, somites, and vasculature development, and have implications for pathological events, including cancer and bone disease. It is not surprising that agents targeting Dkk1 and sclerostin are currently in clinical trials. BHQ880, an anti-Dkk1 neutralizing antibody, is being investigated as an osteoblastogenesis stimulator for the potential treatment of bone lesions in multiple myeloma patients (Fulciniti et al. 2009), and anti-sclerostin monoclonal antibody AMG 785 is being examined for the potential treatment of diseases associated with bone loss, including osteoporosis (Lewiecki 2011; Padhi et al. 2011). Moreover, because of its potent proliferative effect on the intestinal epithelium in vivo and in vitro, Rspol holds promise as therapeutic target for gastrointestinal diseases and regenerative medicine (Kim et al. 2005; Ootani et al. 2009; Sato et al. 2009).

It has become evident that beyond the regulation of Wnt signaling, Wnt inhibitors and activators do modulate other signaling cascades as well, and we will benefit from future research to fully understand their Wnt-dependent and -independent roles.

\section{ACKNOWLEDGMENTS}

We thank B. Engelhardt for artwork. This work is supported by the Deutsche Forschungsgemeinschaft.

\section{REFERENCES}

Adamska M, MacDonald BT, Sarmast ZH, Oliver ER, Meisler MH. 2004. En1 and Wnt7a interact with Dkk1 during limb development in the mouse. Dev Biol 272: 134-144.

Aguilera O, Fraga MF, Ballestar E, Paz MF, Herranz M, Espada J, Garcia JM, Munoz A, Esteller M, GonzalezSancho JM. 2006. Epigenetic inactivation of the Wnt antagonist DICKKOPF-1 (DKK-1) gene in human colorectal cancer. Oncogene 25: 4116-4121.
Ahn Y, Sanderson BW, Klein OD, Krumlauf R. 2010. Inhibition of Wnt signaling by Wise (Sostdc1) and negative feedback from Shh controls tooth number and patterning. Development 137: 3221-3231.

Ai M, Holmen SL, Van Hul W, Williams BO, Warman ML. 2005. Reduced affinity to and inhibition by DKK1 form a common mechanism by which high bone mass-associated missense mutations in LRP5 affect canonical Wnt signaling. Mol Cell Biol 25: 4946-4955.

Aoki M, Mieda M, Ikeda T, Hamada Y, Nakamura H, Okamoto H. 2007. R-Spondin3 is required for mouse placental development. Dev Biol 301: 218-226.

Aoki M, Kiyonari H, Nakamura H, Okamoto H. 2008. RSpondin2 expression in the apical ectodermal ridge is essential for outgrowth and patterning in mouse limb development. Dev Growth Differ 50: 85-95.

Avsian-Kretchmer O, Hsueh AJ. 2004. Comparative genomic analysis of the eight-membered ring cystine knotcontaining bone morphogenetic protein antagonists. Mol Endocrinol 18: 1-12.

Bafico A, Gazit A, Pramila T, Finch PW, Yaniv A, Aaronson SA. 1999. Interaction of frizzled related protein (FRP) with Wnt ligands and the frizzled receptor suggests alternative mechanisms for FRP inhibition of Wnt signaling. J Biol Chem 274: 16180-16187.

Bafico A, Liu G, Yaniv A, Gazit A, Aaronson SA. 2001. Novel mechanism of Wnt signalling inhibition mediated by Dickkopf-1 interaction with LRP6/Arrow. Nat Cell Biol 3: $683-686$.

Balemans W, Ebeling M, Patel N, Van Hul E, Olson P, Dioszegi M, Lacza C, Wuyts W, Van Den Ende J, Willems P, et al. 2001. Increased bone density in sclerosteosis is due to the deficiency of a novel secreted protein (SOST). Hum Mol Genet 10: 537-543.

Balemans W, Patel N, Ebeling M, Van Hul E, Wuyts W, Lacza C, Dioszegi M, Dikkers FG, Hildering P, Willems PJ, et al. 2002. Identification of a $52 \mathrm{~kb}$ deletion downstream of the SOST gene in patients with van $\mathrm{Bu}$ chem disease. J Med Genet 39: 91-97.

Banyai L, Patthy L. 1999. The NTR module: Domains of netrins, secreted frizzled related proteins, and type I procollagen C-proteinase enhancer protein are homologous with tissue inhibitors of metalloproteases. Protein Sci 8: 1636-1642.

Baran R, Kechijian P. 2001. Understanding nail disorders. Eur J Dermatol 11: 159-162.

Barker N, Clevers H. 2010. Leucine-rich repeat-containing G-protein-coupled receptors as markers of adult stem cells. Gastroenterology 138: 1681-1696.

Barrantes Idel B, Montero-Pedrazuela A, Guadano-Ferraz A, Obregon MJ, Martinez de Mena R, Gailus-Durner V, Fuchs H, Franz TJ, Kalaydjiev S, Klempt M, et al. 2006. Generation and characterization of dickkopf3 mutant mice. Mol Cell Biol 26: 2317-2326.

Barrow JR, Thomas KR, Boussadia-Zahui O, Moore R, Kemler R, Capecchi MR, McMahon AP. 2003. Ectodermal Wnt3/ $\beta$-catenin signaling is required for the establishment and maintenance of the apical ectodermal ridge. Genes Dev 17: 394-409.

Bell SM, Schreiner CM, Wert SE, Mucenski ML, Scott WJ, Whitsett JA. 2008. R-Spondin 2 is required for normal 
laryngeal-tracheal, lung and limb morphogenesis. Development 135: 1049-1058.

Belo JA, Bachiller D, Agius E, Kemp C, Borges AC, Marques S, Piccolo S, De Robertis EM. 2000. Cerberuslike is a secreted BMP and nodal antagonist not essential for mouse development. Genesis 26: 265-270.

Belo JA, Silva AC, Borges AC, Filipe M, Bento M, Goncalves L, Vitorino M, Salgueiro AM, Texeira V, Tavares AT, et al. 2009. Generating asymmetries in the early vertebrate embryo: The role of the Cerberus-like family. Int J Dev Biol 53: 1399-1407.

Berger W. 1998. Molecular dissection of Norrie disease. Acta Anat (Basel) 162: 95-100.

Berger W, Meindl A, van de Pol TJ, Cremers FP, Ropers HH, Doerner C, Monaco A, Bergen AA, Lebo R, Warburgh M, et al. 1992. Isolation of a candidate gene for Norrie disease by positional cloning. Nat Genet 2: 84 .

Bergmann C, Senderek J, Anhuf D, Thiel CT, Ekici AB, Poblete-Gutierrez P, van Steensel M, Seelow D, Nurnberg G, Schild HH, et al. 2006. Mutations in the gene encoding the Wnt-signaling component R-spondin 4 (RSPO4) cause autosomal recessive anonychia. Am J Hum Genet 79: 1105-1109.

Bhat RA, Stauffer B, Komm BS, Bodine PV. 2007. Structurefunction analysis of secreted frizzled-related protein-1 for its Wnt antagonist function. J Cell Biochem 102: 1519-1528.

Binnerts ME, Kim KA, Bright JM, Patel SM, Tran K, Zhou M, Leung JM, Liu Y, Lomas WE III, Dixon M, et al. 2007. R-Spondin1 regulates Wnt signaling by inhibiting internalization of LRP6. Proc Natl Acad Sci 104: 14700-14705.

Blaydon DC, Ishii Y, O'Toole EA, Unsworth HC, Teh MT, Ruschendorf F, Sinclair C, Hopsu-Havu VK, Tidman N, Moss C, et al. 2006. The gene encoding R-spondin 4 (RSPO4), a secreted protein implicated in Wnt signaling, is mutated in inherited anonychia. Nat Genet 38: 1245-1247.

Blish KR, Wang W, Willingham MC, Du W, Birse CE, Krishnan SR, Brown JC, Hawkins GA, Garvin AJ, D’Agostino RB Jr, et al. 2008. A human bone morphogenetic protein antagonist is down-regulated in renal cancer. Mol Biol Cell 19: 457-464.

Bouwmeester T, Kim S, Sasai Y, Lu B, De Robertis EM. 1996. Cerberus is a head-inducing secreted factor expressed in the anterior endoderm of Spemann's organizer. Nature 382: 595-601.

Bovolenta P, Esteve P, Ruiz JM, Cisneros E, Lopez-Rios J. 2008. Beyond Wnt inhibition: New functions of secreted Frizzled-related proteins in development and disease. $J$ Cell Sci 121: 737-746.

Boyden LM, Mao J, Belsky J, Mitzner L, Farhi A, Mitnick MA, Wu D, Insogna K, Lifton RP. 2002. High bone density due to a mutation in LDL-receptor-related protein 5. N Engl J Med 346: 1513-1521.

Bradley L, Sun B, Collins-Racie L, LaVallie E, McCoy J, Sive H. 2000. Different activities of the frizzled-related proteins frzb2 and sizzled 2 during Xenopus anteroposterior patterning. Dev Biol 227: 118-132.

Brott BK, Sokol SY. 2002. Regulation of Wnt/LRP signaling by distinct domains of Dickkopf proteins. Mol Cell Biol 22: $6100-6110$.
Bruchle NO, Frank J, Frank V, Senderek J, Akar A, Koc E, Rigopoulos D, van Steensel M, Zerres K, Bergmann C. 2008. RSPO4 is the major gene in autosomal-recessive anonychia and mutations cluster in the furin-like cysteine-rich domains of the Wnt signaling ligand R-spondin 4. J Invest Dermatol 128: 791-796.

Brunkow ME, Gardner JC, Van Ness J, Paeper BW, Kovacevich BR, Proll S, Skonier JE, Zhao L, Sabo PJ, Fu Y, et al. 2001. Bone dysplasia sclerosteosis results from loss of the SOST gene product, a novel cystine knot-containing protein. Am J Hum Genet 68: 577-589.

Cappuccio I, Calderone A, Busceti CL, Biagioni F, Pontarelli F, Bruno V, Storto M, Terstappen GT, Gaviraghi G, Fornai F, et al. 2005. Induction of Dickkopf-1, a negative modulator of the Wnt pathway, is required for the development of ischemic neuronal death. $J$ Neurosci 25: 2647-2657.

Caricasole A, Copani A, Caraci F, Aronica E, Rozemuller AJ, Caruso A, Storto M, Gaviraghi G, Terstappen GC, Nicoletti F. 2004. Induction of Dickkopf-1, a negative modulator of the Wnt pathway, is associated with neuronal degeneration in Alzheimer's brain. J Neurosci 24: 6021-6027.

Carmon KS, Gong X, Lin Q, Thomas A, Liu Q. 2011. RSpondins function as ligands of the orphan receptors LGR4 and LGR5 to regulate Wnt/ $\beta$-catenin signaling. Proc Natl Acad Sci 108: 11452-11457.

Carmon KS, Lin Q, Gong X, Thomas A, Liu Q. 2012. LGR5 interacts and cointernalizes with Wnt receptors to modulate Wnt $/ \beta$-catenin signaling. Mol Cell Biol 32: 2054-2064.

Chapman SC, Brown R, Lees L, Schoenwolf GC, Lumsden A. 2004. Expression analysis of chick Wnt and Frizzled genes and selected inhibitors in early chick patterning. Dev Dyn 229: $668-676$.

Chassot AA, Ranc F, Gregoire EP, Roepers-Gajadien HL, Taketo MM, Camerino G, de Rooij DG, Schedl A, Chaboissier MC. 2008. Activation of $\beta$-catenin signaling by Rspol controls differentiation of the mammalian ovary. Hum Mol Genet 17: 1264-1277.

Chen ZY, Hendriks RW, Jobling MA, Powell JF, Breakefield XO, Sims KB, Craig IW. 1992. Isolation and characterization of a candidate gene for Norrie disease. Nat Genet 1: 204-208.

Chen ZY, Battinelli EM, Fielder A, Bundey S, Sims K, Breakefield XO, Craig IW. 1993. A mutation in the Norrie disease gene (NDP) associated with X-linked familial exudative vitreoretinopathy. Nat Genet 5: 180-183.

Chen JZ, Wang S, Tang R, Yang QS, Zhao E, Chao Y, Ying K, Xie Y, Mao YM. 2002. Cloning and identification of a cDNA that encodes a novel human protein with thrombospondin type I repeat domain, hPWTSR. Mol Biol Rep 29: $287-292$.

Chien AJ, Conrad WH, Moon RT. 2009. A Wnt survival guide: From flies to human disease. J Invest Dermatol 129: $1614-1627$.

Chong JM, Uren A, Rubin JS, Speicher DW. 2002. Disulfide bond assignments of secreted Frizzled-related protein-1 provide insights about Frizzled homology and netrin modules. J Biol Chem 277: 5134-5144. 
Collette NM, Genetos DC, Murugesh D, Harland RM, Loots GG. 2010. Genetic evidence that SOST inhibits WNT signaling in the limb. Dev Biol 342: 169-179.

Dann CE, Hsieh JC, Rattner A, Sharma D, Nathans J, Leahy DJ. 2001. Insights into Wnt binding and signalling from the structures of two Frizzled cysteine-rich domains. Nature 412: 86-90.

Davidson G, Mao B, Del Barco Barrantes I, Niehrs C. 2002. Kremen proteins interact with Dickkopf1 to regulate anteroposterior CNS patterning. Development 129: 5587-5596.

de Lau W, Barker N, Low TY, Koo BK, Li VS, Teunissen H, Kujala P, Haegebarth A, Peters PJ, van de Wetering, et al. 2011. Lgr5 homologues associate with Wnt receptors and mediate R-spondin signalling. Nature 476: 293-297.

del Barco Barrantes I, Davidson G, Grone HJ, Westphal H, Niehrs C. 2003. Dkk1 and noggin cooperate in mammalian head induction. Genes Dev 17: 2239-2244.

Dennis S, Aikawa M, Szeto W, d'Amore PA, Papkoff J. 1999. A secreted Frizzled related protein, FrzA, selectively associates with Wnt-1 protein and regulates Wnt-1 signaling. J Cell Sci 112: 3815-3820.

De Robertis EM, Kuroda H. 2004. Dorsal-ventral patterning and neural induction in Xenopus embryos. Annu Rev Cell Dev Biol 20: 285-308.

Diep DB, Hoen N, Backman M, Machon O, Krauss S. 2004. Characterisation of the Wnt antagonists and their response to conditionally activated Wnt signalling in the developing mouse forebrain. Brain Res Dev Brain Res 153: 261-270.

Durai R, Davies M, Yang W, Yang SY, Seifalian A, Goldspink G, Winslet M. 2006. Biology of insulin-like growth factor binding protein-4 and its role in cancer (review). Int J Oncol 28: 1317-1325.

Ellies DL, Viviano B, McCarthy J, Rey JP, Itasaki N, Saunders S, Krumlauf R. 2006. Bone density ligand, Sclerostin, directly interacts with LRP5 but not LRP5G171V to modulate Wnt activity. J Bone Miner Res 21: 17381749.

Ellwanger K, Saito H, Clement-Lacroix P, Maltry N, Niedermeyer J, Lee WK, Baron R, Rawadi G, Westphal H, Niehrs C. 2008. Targeted disruption of the Wnt regulator Kremen induces limb defects and high bone density. Mol Cell Biol 28: 4875-4882.

Elston MS, Clifton-Bligh RJ. 2010. Identification of Wnt family inhibitors: A pituitary tumor directed whole genome approach. Mol Cell Endocrinol 326: 48-54.

Esteve P, Bovolenta P. 2010. The advantages and disadvantages of Sfrp1 and Sfrp2 expression in pathological events. Tohoku J Exp Med 221: 11-17.

Esteve P, Sandonis A, Cardozo M, Malapeira J, Ibanez C, Crespo I, Marcos S, Gonzalez-Garcia S, Toribio ML, Arribas J, et al. 2011. SFRPs act as negative modulators of ADAM10 to regulate retinal neurogenesis. Nat Neurosci 14: $562-569$.

Fedders H, Augustin R, Bosch TC. 2004. A Dickkopf-3-related gene is expressed in differentiating nematocytes in the basal metazoan Hydra. Dev Genes Evol 214: 72-80.

Finch PW, He X, Kelley MJ, Uren A, Schaudies RP, Popescu NC, Rudikoff S, Aaronson SA, Varmus HE, Rubin JS. 1997. Purification and molecular cloning of a secreted, Frizzled-related antagonist of Wnt action. Proc Natl Acad Sci 94: 6770-6775.

Firth SM, Baxter RC. 2002. Cellular actions of the insulinlike growth factor binding proteins. Endocr Rev 23: 824-854.

Fjeld K, Kettunen P, Furmanek T, Kvinnsland IH, Luukko K. 2005. Dynamic expression of Wnt signaling-related Dickkopf1, -2, and -3 mRNAs in the developing mouse tooth. Dev Dyn 233: 161-166.

Fulciniti M, Tassone P, Hideshima T, Vallet S, Nanjappa P, Ettenberg SA, Shen Z, Patel N, Tai YT, Chauhan D, et al. 2009. Anti-DKK1 mAb (BHQ880) as a potential therapeutic agent for multiple myeloma. Blood 114: 371-379.

Furushima K, Yamamoto A, Nagano T, Shibata M, Miyachi $\mathrm{H}$, Abe $\mathrm{T}$, Ohshima $\mathrm{N}$, Kiyonari $\mathrm{H}$, Aizawa $\mathrm{S}$. 2007. Mouse homologues of Shisa antagonistic to Wnt and Fgf signalings. Dev Biol 306: 480-492.

Galli LM, Barnes T, Cheng T, Acosta L, Anglade A, Willert K, Nusse R, Burrus LW. 2006. Differential inhibition of Wnt-3a by Sfrp-1, Sfrp-2, and Sfrp-3. Dev Dyn 235: 681-690.

Glinka A, Wu W, Onichtchouk D, Blumenstock C, Niehrs C. 1997. Head induction by simultaneous repression of Bmp and Wnt signalling in Xenopus. Nature 389: 517519.

Glinka A, Wu W, Delius H, Monaghan AP, Blumenstock C, Niehrs C. 1998. Dickkopf-1 is a member of a new family of secreted proteins and functions in head induction. Nature 391: 357-362.

Glinka A, Dolde C, Kirsch N, Huang YL, Kazanskaya O, Ingelfinger D, Boutros M, Cruciat CM, Niehrs C. 2011. LGR4 and LGR5 are R-spondin receptors mediating Wnt $/ \beta$-catenin and Wnt/PCP signalling. EMBO Rep 12: $1055-1061$.

Gong Y, Slee RB, Fukai N, Rawadi G, Roman-Roman S, Reginato AM, Wang H, Cundy T, Glorieux FH, Lev D, et al. 2001. LDL receptor-related protein 5 (LRP5) affects bone accrual and eye development. Cell 107: 513-523.

Gonzalez-Sancho JM, Aguilera O, Garcia JM, PendasFranco N, Pena C, Cal S, Garcia de Herreros A, Bonilla F, Munoz A. 2005. The Wnt antagonist DICKKOPF-1 gene is a downstream target of $\beta$-catenin/TCF and is downregulated in human colon cancer. Oncogene 24: 1098-1103.

Gordon A, Southam L, Loughlin J, Wilson AG, Stockley I, Hamer AJ, Eastell R, Wilkinson JM. 2007. Variation in the secreted frizzled-related protein-3 gene and risk of osteolysis and heterotopic ossification after total hip arthroplasty. J Orthop Res 25: 1665-1670.

Grotewold L, Ruther U. 2002. The Wnt antagonist Dickkopf- 1 is regulated by Bmp signaling and c-Jun and modulates programmed cell death. EMBO J 21: 966-975.

Grotewold L, Theil T, Rüther U. 1999. Expression pattern of Dkk-1 during mouse limb development. Mech Dev 89: 151-153.

Guder C, Pinho S, Nacak TG, Schmidt HA, Hobmayer B, Niehrs C, Holstein TW. 2006. An ancient Wnt-Dickkopf antagonism in Hydra. Development 133: 901-911.

Guidato S, Itasaki N. 2007. Wise retained in the endoplasmic reticulum inhibits Wnt signaling by reducing cell surface LRP6. Dev Biol 310: 250-263. 
Hackam AS. 2005. The Wnt signaling pathway in retinal degenerations. IUBMB Life 57: 381-388.

Han XH, Jin YR, Seto M, Yoon JK. 2011. AWNT/ $\beta$-catenin signaling activator, $\mathrm{R}$-spondin, plays positive regulatory roles during skeletal myogenesis. J Biol Chem 286: 10649_ 10659.

Hao HX, Xie Y, Zhang Y, Charlat O, Oster E, Avello M, Lei H, Mickanin C, Liu D, Ruffner H, et al. 2012. ZNRF3 promotes Wnt receptor turnover in an R-spondin-sensitive manner. Nature 485: 195-200.

Hashimoto H, Itoh M, Yamanaka Y, Yamashita S, Shimizu T, Solnica-Krezel L, Hibi M, Hirano T. 2000. Zebrafish Dkk1 functions in forebrain specification and axial mesendoderm formation. Dev Biol 217: 138-152.

Hashimoto H, Rebagliati M, Ahmad N, Muraoka O, Kurokawa T, Hibi M, Suzuki T. 2004. The Cerberus/ Dan-family protein Charon is a negative regulator of Nodal signaling during left-right patterning in zebrafish. Development 131: 1741-1753.

Hausler KD, Horwood NJ, Chuman Y, Fisher JL, Ellis J, Martin TJ, Rubin JS, Gillespie MT. 2004. Secreted frizzled-related protein-1 inhibits RANKL-dependent osteoclast formation. J Bone Miner Res 19: 1873-1881.

Hedge TA, Mason I. 2008. Expression of Shisa2, a modulator of both Wnt and Fgf signaling, in the chick embryo. Int $J$ Dev Biol 52: 81-85.

Hoang B, Moos M Jr, Vukicevic S, Luyten FP. 1996. Primary structure and tissue distribution of FRZB, a novel protein related to Drosophila Frizzled, suggest a role in skeletal morphogenesis. J Biol Chem 271: 26131-26137.

Houart C, Caneparo L, Heisenberg C, Barth K, TakeUchi M, Wilson S. 2002. Establishment of the telencephalon during gastrulation by local antagonism of Wnt signaling. Neuron 35: 255-265.

Hsieh JC, Kodjabachian L, Rebbert ML, Rattner A, Smallwood PM, Samos CH, Nusse R, Dawid IB, Nathans J. 1999. A new secreted protein that binds to Wnt proteins and inhibits their activities. Nature 398: 431-436.

Hu YA, Gu X, Liu J, Yang Y, Yan Y, Zhao C. 2008. Expression pattern of Wnt inhibitor factor 1 (Wif1) during the development in mouse CNS. Gene Expr Patterns 8: 515-522.

Hunter DD, Zhang M, Ferguson JW, Koch M, Brunken WJ. 2004. The extracellular matrix component WIF-1 is expressed during, and can modulate, retinal development. Mol Cell Neurosci 27: 477-488.

Idkowiak J, Weisheit G, Plitzner J, Viebahn C. 2004. Hypoblast controls mesoderm generation and axial patterning in the gastrulating rabbit embryo. Dev Genes Evol 214: 591-605.

Ishii Y, Wajid M, Bazzi H, Fantauzzo KA, Barber AG, Blaydon DC, Nam JS, Yoon JK, Kelsell DP, Christiano AM. 2008. Mutations in R-spondin 4 (RSPO4) underlie inherited anonychia. J Invest Dermatol 128: 867-870.

Itasaki N, Jones CM, Mercurio S, Rowe A, Domingos PM, Smith JC, Krumlauf R. 2003. Wise, a context-dependent activator and inhibitor of Wnt signalling. Development 130: 4295-4305.

Jin YR, Turcotte TJ, Crocker AL, Han XH, Yoon JK. 2011. The canonical Wnt signaling activator, R-spondin2, regulates craniofacial patterning and morphogenesis within the branchial arch through ectodermal-mesenchymal interaction. Dev Biol 352: 1-13.

Jones SE, Jomary C. 2002. Secreted Frizzled-related proteins: Searching for relationships and patterns. Bioessays 24: 811-820.

Jukkola T, Sinjushina N, Partanen J. 2004. Drapcl expression during mouse embryonic development. Gene Expr Patterns 4: 755-762.

Junge HJ, Yang S, Burton JB, Paes K, Shu X, French DM, Costa M, Rice DS, Ye W. 2009. TSPAN12 regulates retinal vascular development by promoting Norrin- but not Wnt-induced FZD4/ $\beta$-catenin signaling. Cell 139: 299311.

Kagermeier-Schenk B, Wehner D, Ozhan-Kizil G, Yamamoto H, Li J, Kirchner K, Hoffmann C, Stern P, Kikuchi A, Schambony A, et al. 2011. Waif1/5T4 inhibits $\mathrm{Wnt} / \beta$-catenin signaling and activates noncanonical Wnt pathways by modifying LRP6 subcellular localization. Dev Cell 21: 1129-1143.

Kamata T, Katsube K, Michikawa M, Yamada M, Takada S, Mizusawa H. 2004. R-spondin, a novel gene with thrombospondin type 1 domain, was expressed in the dorsal neural tube and affected in Whts mutants. Biochim Biophys Acta 1676: 51-62.

Kaneko KJ, DePamphilis ML. 2000. Soggy, a spermatocytespecific gene, lies $3.8 \mathrm{~kb}$ upstream of and antipodal to $T E A D-2$, a transcription factor expressed at the beginning of mouse development. Nucleic Acids Res 28: 3982-3990.

Kansara M, Tsang M, Kodjabachian L, Sims NA, Trivett MK, Ehrich M, Dobrovic A, Slavin J, Choong PF, Simmons PJ, et al. 2009. Wnt inhibitory factor 1 is epigenetically silenced in human osteosarcoma, and targeted disruption accelerates osteosarcomagenesis in mice. J Clin Invest 119: $837-851$.

Kassai Y, Munne P, Hotta Y, Penttila E, Kavanagh K, Ohbayashi N, Takada S, Thesleff I, Jernvall J, Itoh N. 2005. Regulation of mammalian tooth cusp patterning by ectodin. Science 309: 2067-2070.

Katoh Y, Katoh M. 2005. Comparative genomics on Shisa orthologs. Int J Mol Med 16: 181-185.

Kawano Y, Kypta R. 2003. Secreted antagonists of the Wnt signalling pathway. J Cell Sci 116: 2627-2634.

Kazanskaya O, Glinka A, Del Barco Barrantes I, Stannek P, Niehrs C, Wu W. 2004. R-Spondin2 is a secreted activator of Wnt $/ \beta$-catenin signaling and is required for Xenopus myogenesis. Dev Cell 7: 525-534.

Kazanskaya O, Ohkawara B, Heroult M, Wu W, Maltry N, Augustin HG, Niehrs C. 2008. The Wnt signaling regulator R-spondin 3 promotes angioblast and vascular development. Development 135: 3655-3664.

Kelly OG, Pinson KI, Skarnes WC. 2004. The Wnt co-receptors Lrp5 and Lrp6 are essential for gastrulation in mice. Development 131: 2803-2815.

Kim KA, Kakitani M, Zhao J, Oshima T, Tang T, Binnerts M, Liu Y, Boyle B, Park E, Emtage P, et al. 2005. Mitogenic influence of human R-spondin1 on the intestinal epithelium. Science 309: 1256-1259.

Kim KA, Zhao J, Andarmani S, Kakitani M, Oshima T, Binnerts ME, Abo A, Tomizuka K, Funk WD. 2006. RSpondin proteins: A novel link to $\beta$-catenin activation. Cell Cycle 5: 23-26. 
Kim KA, Wagle M, Tran K, Zhan X, Dixon MA, Liu S, Gros D, Korver W, Yonkovich S, Tomasevic N, et al. 2008. R-Spondin family members regulate the Wnt pathway by a common mechanism. Mol Biol Cell 19: 2588 2596.

Kimura-Yoshida C, Nakano H, Okamura D, Nakao K, Yonemura S, Belo JA, Aizawa S, Matsui Y, Matsuo I. 2005. Canonical Wnt signaling and its antagonist regulate anterior-posterior axis polarization by guiding cell migration in mouse visceral endoderm. Dev Cell 9: 639-650.

Kohn MJ, Kaneko KJ, DePamphilis ML. 2005. DkkL1 (Soggy), a Dickkopf family member, localizes to the acrosome during mammalian spermatogenesis. Mol Reprod Dev 71: 516-522.

Krishnan V, Bryant HU, Macdougald OA. 2006. Regulation of bone mass by Wnt signaling. J Clin Invest 116: $1202-1209$.

Krupnik VE, Sharp JD, Jiang C, Robison K, Chickering TW, Amaravadi L, Brown DE, Guyot D, Mays G, Leiby K, et al. 1999. Functional and structural diversity of the human Dickkopf gene family. Gene 238: 301-313.

Kuang SQ, Tong WG, Yang H, Lin W, Lee MK, Fang ZH, Wei Y, Jelinek J, Issa JP, Garcia-Manero G. 2008. Genomewide identification of aberrantly methylated promoter associated $\mathrm{CpG}$ islands in acute lymphocytic leukemia. Leukemia 22: 1529-1538.

Kuroda H, Wessely O, De Robertis EM. 2004. Neural induction in Xenopus: requirement for ectodermal and endomesodermal signals via Chordin, Noggin, $\beta$-Catenin, and Cerberus. PLoS Biol 2: E92.

Laurikkala J, Kassai Y, Pakkasjarvi L, Thesleff I, Itoh N. 2003. Identification of a secreted BMP antagonist, ectodin, integrating BMP, FGF, and SHH signals from the tooth enamel knot. Dev Biol 264: 91-105.

Leaf I, Tennessen J, Mukhopadhyay M, Westphal H, Shawlot W. 2006. Sfrp5 is not essential for axis formation in the mouse. Genesis 44: 573-578.

Lee CS, Buttitta LA, May NR, Kispert A, Fan CM. 2000 SHH-N upregulates Sfrp2 to mediate its competitive interaction with WNT1 and WNT4 in the somitic mesoderm. Development 127: 109-118.

Lee HX, Ambrosio AL, Reversade B, De Robertis EM. 2006. Embryonic dorsal-ventral signaling: Secreted frizzled-related proteins as inhibitors of tolloid proteinases. Cell 124: $147-159$.

Lewiecki EM. 2011. Sclerostin monoclonal antibody therapy with AMG 785: A potential treatment for osteoporosis. Expert Opin Biol Ther 11: 117-127.

Leyns L, Bouwmeester T, Kim SH, Piccolo S, De Robertis EM. 1997. Frzb-1 is a secreted antagonist of Wnt signaling expressed in the Spemann organizer. Cell 88: 747-756.

Li L, Mao J, Sun L, Liu W, Wu D. 2002. Second cysteine-rich domain of Dickkopf-2 activates canonical Wnt signaling pathway via LRP-6 independently of Dishevelled. J Biol Chem 277: 5977-5981.

Li X, Liu P, Liu W, Maye P, Zhang J, Zhang Y, Hurley M, Guo C, Boskey A, Sun L, et al. 2005a. Dkk2 has a role in terminal osteoblast differentiation and mineralized matrix formation. Nat Genet 37: 945-952.
Li X, Zhang Y, Kang H, Liu W, Liu P, Zhang J, Harris SE, Wu D. 2005b. Sclerostin binds to LRP5/6 and antagonizes canonical Wnt signaling. J Biol Chem 280: 1988319887.

Li J, Sarosi I, Cattley RC, Pretorius J, Asuncion F, Grisanti M, Morony S, Adamu S, Geng Z, Qiu W, et al. 2006. Dkk1mediated inhibition of Wnt signaling in bone results in osteopenia. Bone 39: 754-766.

Li X, Ominsky MS, Niu QT, Sun N, Daugherty B, D’Agostin D, Kurahara C, Gao Y, Cao J, Gong J, et al. 2008a. Targeted deletion of the sclerostin gene in mice results in increased bone formation and bone strength. $J$ Bone Miner Res 23: 860-869.

Li Y, Rankin SA, Sinner D, Kenny AP, Krieg PA, Zorn AM. 2008b. Sfrp5 coordinates foregut specification and morphogenesis by antagonizing both canonical and noncanonical Wnt11 signaling. Genes Dev 22: 3050-3063.

Li Y, Pawlik B, Elcioglu N, Aglan M, Kayserili H, Yigit G, Percin F, Goodman F, Nurnberg G, Cenani A, et al. 2010. LRP4 mutations alter $\mathrm{Wnt} / \beta$-catenin signaling and cause limb and kidney malformations in Cenani-Lenz syndrome. Am J Hum Genet 86: 696-706.

Li S, Esterberg R, Lachance V, Ren D, Radde-Gallwitz K, Chi F, Parent JL, Fritz A, Chen P. 2011. Rack1 is required for Vangl2 membrane localization and planar cell polarity signaling while attenuating canonical Wnt activity. Proc Natl Acad Sci 108: 2264-2269.

Lin K, Wang S, Julius MA, Kitajewski J, Moos MJ, Luyten FP. 1997. The cysteine-rich frizzled domain of Frzb-1 is required and sufficient for modulation of Wnt signaling. Proc Natl Acad Sci 94: 11196-11200.

Lintern KB, Guidato S, Rowe A, Saldanha JW, Itasaki N. 2009. Characterization of Wise protein and its molecular mechanism to interact with both Wnt and BMP signals. Biol Chem 284: 23159-23168.

Little RD, Carulli JP, Del Mastro RG, Dupuis J, Osborne M, Folz C, Manning SP, Swain PM, Zhao SC, Eustace B, et al. 2002. A mutation in the LDL receptor-related protein 5 gene results in the autosomal dominant high-bone-mass trait. Am J Hum Genet 70: 11-19.

Lopez-Rios J, Esteve P, Ruiz JM, Bovolenta P. 2008. The Netrin-related domain of Sfrp1 interacts with Wnt ligands and antagonizes their activity in the anterior neural plate. Neural Dev 3: 19.

Lowther W, Wiley K, Smith GH, Callahan R. 2005. A new common integration site, Int7, for the mouse mammary tumor virus in mouse mammary tumors identifies a gene whose product has furin-like and thrombospondin-like sequences. J Virol 79: 10093-10096.

Luhmann UF, Lin J, Acar N, Lammel S, Feil S, Grimm C, Seeliger MW, Hammes HP, Berger W. 2005a. Role of the Norrie disease pseudoglioma gene in sprouting angiogenesis during development of the retinal vasculature. Invest Ophthalmol Vis Sci 46: 3372-3382.

Luhmann UF, Meunier D, Shi W, Luttges A, Pfarrer C, Fundele R, Berger W. 2005b. Fetal loss in homozygous mutant Norrie disease mice: A new role of Norrin in reproduction. Genesis 42: 253-262.

Luke GN, Castro LF, McLay K, Bird C, Coulson A, Holland PW. 2003. Dispersal of NK homeobox gene clusters in amphioxus and humans. Proc Natl Acad Sci 100: $5292-5295$. 
MacDonald BT, Adamska M, Meisler MH. 2004. Hypomorphic expression of Dkk1 in the doubleridge mouse: Dose dependence and compensatory interactions with Lrp6. Development 131: 2543-2552.

MacDonald BT, Joiner DM, Oyserman SM, Sharma P, Goldstein SA, He X, Hauschka PV. 2007. Bone mass is inversely proportional to $D k k 1$ levels in mice. Bone 41: 331-339.

Mao B, Niehrs C. 2003. Kremen2 modulates Dickkopf2 activity during Wnt/LRP6 signaling. Gene 302: 179-183.

Mao B, Wu W, Li Y, Hoppe D, Stannek P, Glinka A, Niehrs C. 2001. LDL-receptor-related protein 6 is a receptor for Dickkopf proteins. Nature 411: 321-325.

Mao B, Wu W, Davidson G, Marhold J, Li M, Mechler B, Delius H, Hoppe D, Stannek P, et al. 2002. Kremens are novel Dickkopf receptors that regulate Wnt $/ \beta$-catenin signalling. Nature 417: 664-667.

Marques S, Borges AC, Silva AC, Freitas S, Cordenonsi M, Belo JA. 2004. The activity of the Nodal antagonist Cerl-2 in the mouse node is required for correct $\mathrm{L} / \mathrm{R}$ body axis. Genes Dev 18: 2342-2347.

Matsuyama M, Aizawa S, Shimono A. 2009. Sfrp controls apicobasal polarity and oriented cell division in developing gut epithelium. PLoS Genet 5: e1000427.

Meindl A, Berger W, Meitinger T, van de Pol D, Achatz H, Dorner C, Haasemann M, Hellebrand H, Gal A, Cremers F, et al. 1992. Norrie disease is caused by mutations in an extracellular protein resembling C-terminal globular domain of mucins. Nat Genet 2: 139-143.

Meitinger T, Meindl A, Bork P, Rost B, Sander C, Haasemann M, Murken J. 1993. Molecular modelling of the Norrie disease protein predicts a cystine knot growth factor tertiary structure. Nat Genet 5: 376-380.

Melkonyan HS, Chang WC, Shapiro JP, Mahadevappa M, Fitzpatrick PA, Kiefer MC, Tomei LD, Umansky SR. 1997. SARPs: A family of secreted apoptosis-related proteins. Proc Natl Acad Sci 94: 13636-13641.

Mii Y, Taira M. 2009. Secreted Frizzled-related proteins enhance the diffusion of Wnt ligands and expand their signalling range. Development 136: 4083-4088.

Monaghan AP, Kioschis P, Wu W, Zuniga A, Bock D, Poustka A, Delius H, Niehrs C. 1999. Dickkopf genes are co-ordinately expressed in mesodermal lineages. Mech Dev 87: 45-56.

Morvan F, Boulukos K, Clement-Lacroix P, Roman Roman S, Suc-Royer I, Vayssiere B, Ammann P, Martin P, Pinho S, Pognonec P, et al. 2006. Deletion of a single allele of the $D k k 1$ gene leads to an increase in bone formation and bone mass. J Bone Miner Res 21: 934-945.

Mukhopadhyay M, Shtrom S, Rodriguez-Esteban C, Chen L, Tsukui T, Gomer L, Dorward DW, Glinka A, Grinberg A, Huang SP, et al. 2001. Dickkopf1 is required for embryonic head induction and limb morphogenesis in the mouse. Dev Cell 1: 423-434.

Mukhopadhyay M, Gorivodsky M, Shtrom S, Grinberg A, Niehrs C, Morasso MI, Westphal H. 2006. Dkk2 plays an essential role in the corneal fate of the ocular surface epithelium. Development 133: 2149-2154.

Nagano T, Takehara S, Takahashi M, Aizawa S, Yamamoto A. 2006. Shisa2 promotes the maturation of somitic precur- sors and transition to the segmental fate in Xenopus embryos. Development 133: 4643-4654.

Naganuma H, Kono K, Mori Y, Takayoshi S, Stern PL, Tasaka K, Matsumoto Y. 2002. Oncofetal antigen 5T4 expression as a prognostic factor in patients with gastric cancer. Anticancer Res 22: 1033-1038.

Nam JS, Turcotte TJ, Smith PF, Choi S, Yoon JK. 2006. Mouse cristin/R-spondin family proteins are novel ligands for the Frizzled 8 and LRP6 receptors and activate $\beta$-catenin-dependent gene expression. J Biol Chem 281: 13247-13257.

Nam JS, Park E, Turcotte TJ, Palencia S, Zhan X, Lee J, Yun K, Funk WD, Yoon JK. 2007a. Mouse R-spondin2 is required for apical ectodermal ridge maintenance in the hindlimb. Dev Biol 311: 124-135.

Nam JS, Turcotte TJ, Yoon JK. 2007b. Dynamic expression of R-spondin family genes in mouse development. Gene Expr Patterns 7: 306-312.

Nie X. 2005. Dkk1, -2, and -3 expression in mouse craniofacial development. J Mol Histol 36: 367-372.

Nie X, Luukko K, Fjeld K, Kvinnsland IH, Kettunen P. 2005. Developmental expression of Dkk1-3 and Mmp9 and apoptosis in cranial base of mice. J Mol Histol 36: 419-426.

Niehrs C. 2004. Regionally specific induction by the Spemann-Mangold organizer. Nat Rev Genet 5: 425-434.

Niehrs C. 2006. Function and biological roles of the Dickkopf family of Wnt modulators. Oncogene 25: 74697481.

Niehrs C. 2010. On growth and form: A Cartesian coordinate system of Wnt and BMP signaling specifies bilaterian body axes. Development 137: 845-857.

Ning Y, Schuller AG, Bradshaw S, Rotwein P, Ludwig T, Frystyk J, Pintar JE. 2006. Diminished growth and enhanced glucose metabolism in triple knockout mice containing mutations of insulin-like growth factor binding protein-3, -4, and -5. Mol Endocrinol 20: 2173-2186.

Ohazama A, Johnson EB, Ota MS, Choi HY, Porntaveetus T, Oommen S, Itoh N, Eto K, Gritli-Linde A, Herz J, et al. 2008. Lrp4 modulates extracellular integration of cell signaling pathways in development. PLoS ONE 3: e4092.

Ohkawara B, Glinka A, Niehrs C. 2011. Rspo3 binds syndecan 4 and induces Wnt/PCP signaling via clathrin-mediated endocytosis to promote morphogenesis. Dev Cell 20: 303-314.

Ootani A, Li X, Sangiorgi E, Ho QT, Ueno H, Toda S, Sugihara H, Fujimoto K, Weissman IL, Capecchi MR, et al. 2009. Sustained in vitro intestinal epithelial culture within a Wnt-dependent stem cell niche. Nat Med 15: 701-706.

O'Shaughnessy RF, Yeo W, Gautier J, Jahoda CA, Christiano AM. 2004. The WNT signalling modulator, Wise, is expressed in an interaction-dependent manner during hair-follicle cycling. J Invest Dermatol 123: 613621.

Padhi D, Jang G, Stouch B, Fang L, Posvar E. 2011. Singledose, placebo-controlled, randomized study of AMG 785, a sclerostin monoclonal antibody. J Bone Miner Res 26: $19-26$.

Parma P, Radi O, Vidal V, Chaboissier MC, Dellambra E, Valentini S, Guerra L, Schedl A, Camerino G. 2006. R- 
C.-M. Cruciat and C. Niehrs

Spondin1 is essential in sex determination, skin differentiation and malignancy. Nat Genet 38: 1304-1309.

Pei J, Grishin NV. 2012. Unexpected diversity in Shisa-like proteins suggests the importance of their roles as transmembrane adaptors. Cell Signal 24: 758-769.

Pera EM, De Robertis EM. 2000. A direct screen for secreted proteins in Xenopus embryos identifies distinct activities for the Wnt antagonists Crescent and Frzb-1. Mech Dev 96: 183-195.

Pfeffer PL, De Robertis EM, Izpisua-Belmonte JC. 1997. Crescent, a novel chick gene encoding a Frizzled-like cysteine-rich domain, is expressed in anterior regions during early embryogenesis. Int J Dev Biol 41: 449-458.

Piccolo S, Agius E, Leyns L, Bhattacharyya S, Grunz H, Bouwmeester T, De Robertis EM. 1999. The head inducer Cerberus is a multifunctional antagonist of Nodal, BMP and Wnt signals. Nature 397: 707-710.

Pinho S, Niehrs C. 2007. Dkk3 is required for TGF- $\beta$ signaling during Xenopus mesoderm induction. Differentiation 75: 957-967.

Pollard SL, Holland PW. 2000. Evidence for 14 homeobox gene clusters in human genome ancestry. Curr Biol 10: 1059-1062.

Rattner A, Hsieh J-C, Smallwood PM, Gilbert D, Copeland NG, Jenkins NA, Nathans J. 1997. A family of secreted proteins contains homology to the cysteine-rich ligand binding domain of frizzled receptors. Proc Natl Acad Sci 94: 2859-2863.

Rehm HL, Zhang DS, Brown MC, Burgess B, Halpin C, Berger W, Morton CC, Corey DP, Chen ZY. 2002. Vascular defects and sensorineural deafness in a mouse model of Norrie disease. J Neurosci 22: 4286-4292.

Rehn M, Pihlajaniemi T, Hofmann K, Bucher P. 1998. The frizzled motif: In how many different protein families does it occur? Trends Biochem Sci 23: 415-417.

Richter M, Gottanka J, May CA, Welge-Lussen U, Berger W, Lutjen-Drecoll E. 1998. Retinal vasculature changes in Norrie disease mice. Invest Ophthalmol Vis Sci 39: 2450-2457.

Robitaille J, MacDonald ML, Kaykas A, Sheldahl LC, Zeisler J, Dube MP, Zhang LH, Singaraja RR, Guernsey DL, Zheng B, et al. 2002. Mutant frizzled-4 disrupts retinal angiogenesis in familial exudative vitreoretinopathy. Nat Genet 32: 326-330.

Rodriguez Esteban C, Capdevila J, Economides AN, Pascual J, Ortiz A, Izpisua Belmonte JC. 1999. The novel Cer-like protein Caronte mediates the establishment of embryonic left-right asymmetry. Nature 401: 243-251.

Rodriguez J, Esteve P, Weinl C, Ruiz JM, Fermin Y, Trousse F, Dwivedy A, Holt C, Bovolenta P. 2005. SFRP1 regulates the growth of retinal ganglion cell axons through the Fz2 receptor. Nat Neurosci 8: 1301-1309.

Salic AN, Kroll KL, Evans LM, Kirschner MW. 1997. Sizzled: A secreted Xwnt8 antagonist expressed in the ventral marginal zone of Xenopus embryos. Development 124: 4739-4748.

Sato H, Suzuki H, Toyota M, Nojima M, Maruyama R, Sasaki S, Takagi H, Sogabe Y, Sasaki Y, Idogawa M, et al. 2007. Frequent epigenetic inactivation of DICKKOPF family genes in human gastrointestinal tumors. Carcinogenesis 28: $2459-2466$.
Sato T, Vries RG, Snippert HJ, van de Wetering M, Barker N, Stange DE, van Es JH, Abo A, Kujala P, Peters PJ, et al. 2009. Single Lgr5 stem cells build crypt-villus structures in vitro without a mesenchymal niche. Nature 459: $262-265$.

Satoh W, Gotoh T, Tsunematsu Y, Aizawa S, Shimono A. 2006. Sfrp1 and Sfrp2 regulate anteroposterior axis elongation and somite segmentation during mouse embryogenesis. Development 133: 989-999.

Satoh W, Matsuyama M, Takemura H, Aizawa S, Shimono A. 2008. Sfrp1, Sfrp2, and Sfrp5 regulate the Wnt/ $\beta$-catenin and the planar cell polarity pathways during early trunk formation in mouse. Genesis 46: 92-103.

Schneider VA, Mercola M. 2001. Wnt antagonism initiates cardiogenesis in Xenopus laevis. Genes Dev 15: 304-315.

Schwarz-Romond T, Asbrand C, Bakkers J, Kuhl M, Schaeffer HJ, Huelsken J, Behrens J, Hammerschmidt M, Birchmeier W. 2002. The ankyrin repeat protein Diversin recruits Casein kinase I $\varepsilon$ to the $\beta$-catenin degradation complex and acts in both canonical Wnt and Wnt/JNK signaling. Genes Dev 16: 2073-2084.

Semenov MV, He X. 2006. LRP5 mutations linked to high bone mass diseases cause reduced LRP5 binding and inhibition by SOST. J Biol Chem 281: 38276-38284.

Semenov MV, Tamai K, Brott BK, Kuhl M, Sokol S, He X. 2001. Head inducer Dickkopf-1 is a ligand for Wnt coreceptor LRP6. Curr Biol 11: 951-961.

Semenov M, Tamai K, He X. 2005. SOST is a ligand for LRP5/LRP6 and a Wnt signaling inhibitor. J Biol Chem 280: $26770-26775$.

Semenov MV, Zhang X, He X. 2008. DKK1 antagonizes Wnt signaling without promotion of LRP6 internalization and degradation. J Biol Chem 283: 21427-21432.

Shawlot W, Min Deng J, Wakamiya M, Behringer RR. 2000. The cerberus-related gene, Cerr1, is not essential for mouse head formation. Genesis 26: 253-258.

Shimomura Y, Agalliu D, Vonica A, Luria V, Wajid M, Baumer A, Belli S, Petukhova L, Schinzel A, Brivanlou AH, et al. 2010. APCDD1 is a novel Wnt inhibitor mutated in hereditary hypotrichosis simplex. Nature 464: 1043-1047.

Shinya M, Eschbach C, Clark M, Lehrach H, FurutaniSeiki M. 2000. Zebrafish Dkk1, induced by the preMBT Wnt signaling, is secreted from the prechordal plate and patterns the anterior neural plate. Mech Dev 98: $3-17$.

Silva AC, Filipe M, Kuerner KM, Steinbeisser H, Belo JA. 2003. Endogenous Cerberus activity is required for anterior head specification in Xenopus. Development 130: 4943-4953.

Silva AC, Filipe M, Vitorino M, Steinbeisser H, Belo JA. 2006. Developmental expression of Shisa-2 in Xenopus laevis. Int J Dev Biol 50: 575-579.

Simons M, Gloy J, Ganner A, Bullerkotte A, Bashkurov M, Kronig C, Schermer B, Benzing T, Cabello OA, Jenny A, et al. 2005. Inversin, the gene product mutated in nephronophthisis type II, functions as a molecular switch between Wnt signaling pathways. Nat Genet 37: 537-543.

Simpson EH, Johnson DK, Hunsicker P, Suffolk R, Jordan SA, Jackson IJ. 1999. The mouse Cerl (Cerberus 
related or homologue) gene is not required for anterior pattern formation. Dev Biol 213: 202-206.

Smallwood PM, Williams J, Xu Q, Leahy DJ, Nathans J. 2007. Mutational analysis of Norrin-Frizzled4 recognition. J Biol Chem 282: 4057-4068.

Soshnikova N, Zechner D, Huelsken J, Mishina Y, Behringer RR, Taketo MM, Crenshaw EB III, Birchmeier W. 2003. Genetic interaction between Wnt $/ \beta$-catenin and BMP receptor signaling during formation of the AER and the dorsal-ventral axis in the limb. Genes Dev 17: 1963-1968.

Southgate TD, McGinn OJ, Castro FV, Rutkowski AJ, AlMuftah M, Marinov G, Smethurst GJ, Shaw D, Ward CM, Miller CJ, et al. 2010. CXCR4 mediated chemotaxis is regulated by 5T4 oncofetal glycoprotein in mouse embryonic cells. PLoS ONE 5: e9982.

Staehling-Hampton K, Proll S, Paeper BW, Zhao L, Charmley P, Brown A, Gardner JC, Galas D, Schatzman RC, Beighton P, et al. 2002. A 52-kb deletion in the SOSTMEOX1 intergenic region on $17 \mathrm{q} 12-\mathrm{q} 21$ is associated with van Buchem disease in the Dutch population. Am J Med Genet 110: 144-152.

Stanley EG, Biben C, Allison J, Hartley L, Wicks IP, Campbell IK, McKinley M, Barnett L, Koentgen F, Robb L, et al. 2000. Targeted insertion of a lacZ reporter gene into the mouse Cerl locus reveals complex and dynamic expression during embryogenesis. Genesis 26: 259-264.

Starr TK, Allaei R, Silverstein KA, Staggs RA, Sarver AL, Bergemann TL, Gupta M, O'Sullivan MG, Matise I, Dupuy AJ, et al. 2009. A transposon-based genetic screen in mice identifies genes altered in colorectal cancer. Science 323: 1747-1750.

Starzynska T, Marsh PJ, Schofield PF, Roberts SA, Myers KA, Stern PL. 1994. Prognostic significance of 5T4 oncofetal antigen expression in colorectal carcinoma. $\mathrm{Br} \mathrm{J}$ Cancer 69: 899-902.

Sugiyama Y, Stump RJ, Nguyen A, Wen L, Chen Y, Wang Y, Murdoch JN, Lovicu FJ, McAvoy JW. 2010. Secreted frizzled-related protein disrupts PCP in eye lens fiber cells that have polarised primary cilia. Dev Biol 338: 193-201.

Surmann-Schmitt C, Widmann N, Dietz U, Saeger B, Eitzinger N, Nakamura Y, Rattel M, Latham R, Hartmann C, von der Mark H, et al. 2009. Wif- 1 is expressed at cartilage-mesenchyme interfaces and impedes Wnt3a-mediated inhibition of chondrogenesis. J Cell Sci 122: $3627-3637$.

Swain RK, Katoh M, Medina A, Steinbeisser H. 2005. Xenopus frizzled-4S, a splicing variant of $X f z 4$ is a contextdependent activator and inhibitor of Wnt $/ \beta$-catenin signaling. Cell Commun Signal 3: 12.

Takahashi M, Fujita M, Furukawa Y, Hamamoto R, Shimokawa T, Miwa N, Ogawa M, Nakamura Y. 2002. Isolation of a novel human gene, APCDD1, as a direct target of the $\beta$-catenin/T-cell factor 4 complex with probable involvement in colorectal carcinogenesis. Cancer Res 62: 5651-5656.

Tavares AT, Andrade S, Silva AC, Belo JA. 2007. Cerberus is a feedback inhibitor of Nodal asymmetric signaling in the chick embryo. Development 134: 2051-2060.

Theodorou V, Kimm MA, Boer M, Wessels L, Theelen W, Jonkers J, Hilkens J. 2007. MMTV insertional mutagen- esis identifies genes, gene families and pathways involved in mammary cancer. Nat Genet 39: 759-769.

Tomaselli S, Megiorni F, De Bernardo C, Felici A, Marrocco G, Maggiulli G, Grammatico B, Remotti D, Saccucci P, Valentini F, et al. 2008. Syndromic true hermaphroditism due to an R-spondin1 (RSPO1) homozygous mutation. Hum Mutat 29: 220-226.

Tomizuka K, Horikoshi K, Kitada R, Sugawara Y, Iba Y, Kojima A, Yoshitome A, Yamawaki K, Amagai M, Inoue A, et al. 2008. R-Spondin1 plays an essential role in ovarian development through positively regulating Wnt-4 signaling. Hum Mol Genet 17: 1278-1291.

Toomes C, Bottomley HM, Jackson RM, Towns KV, Scott S, Mackey DA, Craig JE, Jiang L, Yang Z, Trembath R, et al. 2004a. Mutations in LRP5 or FZD4 underlie the common familial exudative vitreoretinopathy locus on chromosome 11q. Am J Hum Genet 74: 721-730.

Toomes C, Bottomley HM, Scott S, Mackey DA, Craig JE, Appukuttan B, Stout JT, Flaxel CJ, Zhang K, Black GC, et al. 2004b. Spectrum and frequency of FZD4 mutations in familial exudative vitreoretinopathy. Invest Ophthalmol Vis Sci 45: 2083-2090.

Uren A, Reichsman F, Anest V, Taylor WG, Muraiso K, Bottaro DP, Cumberledge S, Rubin JS. 2000. Secreted frizzled-related protein-1 binds directly to Wingless and is a biphasic modulator of Wnt signaling. J Biol Chem 275: $4374-4382$.

Vainio S, Heikkila M, Kispert A, Chin N, McMahon AP. 1999. Female development in mammals is regulated by Wnt-4 signalling. Nature 397: 405-409.

Vonica A, Brivanlou AH. 2007. The left-right axis is regulated by the interplay of Coco, Xnrl and derrière in Xenopus embryos. Dev Biol 303: 281-294.

Wang S, Krinks M, Lin K, Luyten FP, Moos M Jr. 1997. Frzb, a secreted protein expressed in the Spemann organizer, binds and inhibits Wnt-8. Cell 88: 757-766.

Wang K, Zhang Y, Li X, Chen L, Wang H, Wu J, Zheng J, Wu D. 2008. Characterization of the Kremen-binding site on Dkk1 and elucidation of the role of Kremen in Dkk-mediated Wnt antagonism. J Biol Chem 283: 23371-23375.

Warden SM, Andreoli CM, Mukai S. 2007. The Wnt signaling pathway in familial exudative vitreoretinopathy and Norrie disease. Semin Ophthalmol 22: 211-217.

Warr N, Siggers P, Bogani D, Brixey R, Pastorelli L, Yates L, Dean CH, Wells S, Satoh W, Shimono A, et al. 2009. Sfrp1 and $S f r p 2$ are required for normal male sexual development in mice. Dev Biol 326: 273-284.

Wawrzak D, Metioui M, Willems E, Hendrickx M, de Genst E, Leyns L. 2007. Wnt3a binds to several sFRPs in the nanomolar range. Biochem Biophys Res Commun 357: 1119-1123.

Wei Q, Yokota C, Semenov MV, Doble B, Woodgett J, He X 2007. R-Spondin 1 is a high affinity ligand for LRP6 and induces LRP6 phosphorylation and $\beta$-catenin signaling. J Biol Chem 282: 15903-15911.

Winkler DG, Sutherland MK, Geoghegan JC, Yu C, Hayes T, Skonier JE, Shpektor D, Jonas M, Kovacevich BR, Staehling-Hampton K, et al. 2003. Osteocyte control of bone formation via sclerostin, a novel BMP antagonist. EMBO J 22: 6267-6276. 


\section{C.-M. Cruciat and C. Niehrs}

Wu W, Glinka A, Delius H, Niehrs C. 2000. Mutual antagonism between dickkopfl and dickkopf2 regulates Wnt $/ \beta$ catenin signalling. Curr Biol 10: 1611-1614.

Xia CH, Liu H, Cheung D, Wang M, Cheng C, Du X, Chang B, Beutler B, Gong X. 2008. A model for familial exudative vitreoretinopathy caused by LPR 5 mutations. Hum Mol Genet 17: 1605-1612.

Xu Q, Wang Y, Dabdoub A, Smallwood PM, Williams J, Woods C, Kelley MW, Jiang L, Tasman W, Zhang K, et al. 2004. Vascular development in the retina and inner ear: Control by Norrin and Frizzled-4, a high-affinity ligand-receptor pair. Cell 116: 883-895.

Yamada W, Nagao K, Horikoshi K, Fujikura A, Ikeda E, Inagaki $\mathrm{Y}$, Kakitani $\mathrm{M}$, Tomizuka $\mathrm{K}$, Miyazaki $\mathrm{H}$, Suda T, et al. 2009. Craniofacial malformation in R-spondin2 knockout mice. Biochem Biophys Res Commun 381: 453-458.

Yamamoto A, Nagano T, Takehara S, Hibi M, Aizawa S. 2005. Shisa promotes head formation through the inhibition of receptor protein maturation for the caudalizing factors, Wnt and FGF. Cell 120: 223-235.

Yan D, Wallingford JB, Sun TQ, Nelson AM, Sakanaka C, Reinhard C, Harland RM, Fantl WJ, Williams LT. 2001. Cell autonomous regulation of multiple Dishevelled-dependent pathways by mammalian Nkd. Proc Natl Acad Sci 98: 3802-3807.

Yanagita $M$, Oka $M$, Watabe $T$, Iguchi $H$, Niida $A$, Takahashi S, Akiyama T, Miyazono K, Yanagisawa M, Sakurai T. 2004. USAG-1: A bone morphogenetic protein antagonist abundantly expressed in the kidney. Biochem Biophys Res Commun 316: 490-500.
Yanagita M, Okuda T, Endo S, Tanaka M, Takahashi K, Sugiyama F, Kunita S, Takahashi S, Fukatsu A, Yanagisawa M, et al. 2006. Uterine sensitization-associated gene-1 (USAG-1), a novel BMP antagonist expressed in the kidney, accelerates tubular injury. J Clin Invest 116: 70-79.

Ye X, Smallwood P, Nathans J. 2011. Expression of the Norrie disease gene $(N d p)$ in developing and adult mouse eye, ear, and brain. Gene Expr Patterns 11: 151-155.

Yokouchi Y, Vogan KJ, Pearse RV II, Tabin CJ. 1999. Antagonistic signaling by Caronte, a novel Cerberus-related gene, establishes left-right asymmetric gene expression. Cell 98: 573-583.

Yoon JK, Lee JS. 2012. Cellular signaling and biological functions of R-spondins. Cell Signal 24: 369-377.

Zhang X, Abreu JG, Yokota C, Macdonald BT, Singh S, Coburn KL, Cheong SM, Zhang MM, Ye QZ, Hang HC, et al. 2012. tikil is required for head formation via Wnt cleavage-oxidation and inactivation. Cell 149: 1565-1577.

Zhu L, Marvin MJ, Gardiner A, Lassar AB, Mercola M, Stern CD, Levin M. 1999. Cerberus regulates left-right asymmetry of the embryonic head and heart. Curr Biol 9: 931-938.

Zhu W, Shiojima I, Ito Y, Li Z, Ikeda H, Yoshida M, Naito AT, Nishi J, Ueno H, Umezawa A, et al. 2008a. IGFBP-4 is an inhibitor of canonical Wnt signalling required for cardiogenesis. Nature 454: 345-349.

Zhu Y, Tsuchida A, Yamamoto A, Furukawa K, Tajima O, Tokuda N, Aizawa S, Urano T, Kadomatsu K. 2008b. Expression and roles of a Xenopus head-forming gene homologue in human cancer cell lines. Nagoya J Med Sci 70: $73-82$. 


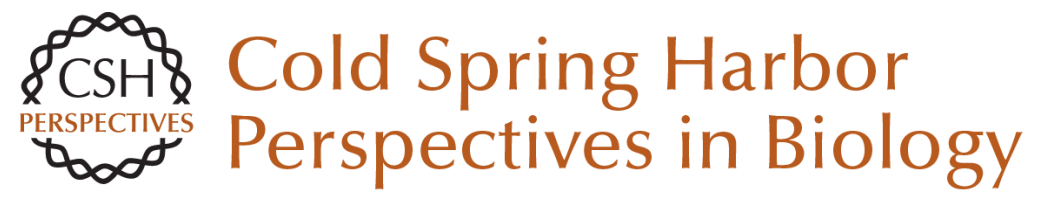

\section{Secreted and Transmembrane Wnt Inhibitors and Activators}

Cristina-Maria Cruciat and Christof Niehrs

Cold Spring Harb Perspect Biol 2013; doi: 10.1101/cshperspect.a015081 originally published online October 19, 2012

\section{Subject Collection Wnt Signaling}

Wnt Signaling in Vertebrate Axis Specification Hiroki Hikasa and Sergei Y. Sokol

Secreted and Transmembrane Wnt Inhibitors and

Activators

Cristina-Maria Cruciat and Christof Niehrs

Wnt Signaling in Normal and Malignant

Hematopoiesis

William Lento, Kendra Congdon, Carlijn Voermans, et al.

Frizzled and LRP5/6 Receptors for Wnt/ $\beta$-Catenin

Signaling

Bryan T. MacDonald and Xi He

TCF/LEFs and Wnt Signaling in the Nucleus

Ken M. Cadigan and Marian L. Waterman

\section{Alternative Wnt Pathways and Receptors \\ Renée van Amerongen}

$\beta$-Catenin-Dependent Wnt Signaling in C. elegans:

Teaching an Old Dog a New Trick

Belinda M. Jackson and David M. Eisenmann

The Evolution of the Wnt Pathway

Thomas W. Holstein
The $\beta$-Catenin Destruction Complex Jennifer L. Stamos and William I. Weis

Wnt Signaling in Skin Development, Homeostasis, and Disease Xinhong Lim and Roel Nusse

Wnt Signaling in Bone Development and Disease:

Making Stronger Bone with Wnts Jean B. Regard, Zhendong Zhong, Bart O. Williams, et al.

Targeting Wnt Pathways in Disease Zachary F. Zimmerman, Randall T. Moon and Andy J. Chien

Wnt Signaling in Mammary Glands: Plastic Cell

Fates and Combinatorial Signaling Caroline M. Alexander, Shruti Goel, Saja A. Fakhraldeen, et al.

Wnt Signaling and Injury Repair Jemima L. Whyte, Andrew A. Smith and Jill A. Helms

Wnt Signaling and Forebrain Development Susan J. Harrison-Uy and Samuel J. Pleasure

Wnt Signaling in Neuromuscular Junction Development

Kate Koles and Vivian Budnik

For additional articles in this collection, see http://cshperspectives.cshlp.org/cgi/collection/

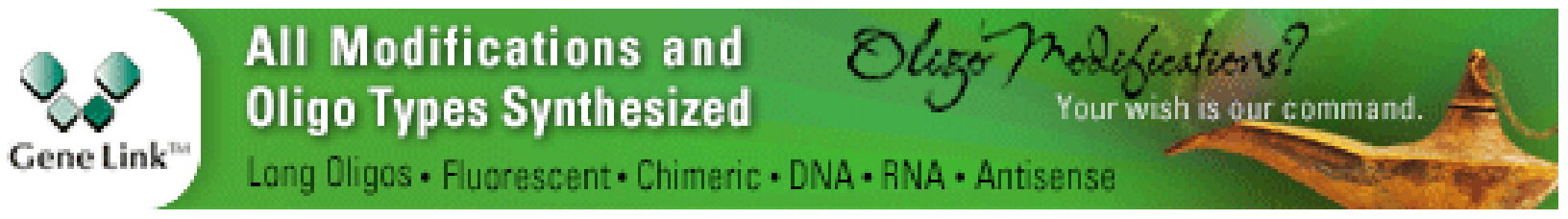

